\title{
Silver-based nanocomposite for fabricating high performance value-added cotton
}

\author{
Chongjun Huang $\cdot$ Yurou Cai $\cdot$ Xi Chen $\cdot$ Yu Ke $\mathbb{C}$
}

Received: 24 April 2021 / Accepted: 6 October 2021/Published online: 24 November 2021

(C) The Author(s), under exclusive licence to Springer Nature B.V. 2021

\begin{abstract}
Cotton is one of the most important cellulose fibers, but the absence of antimicrobial capacity along with the self-cleaning, UV protection and electric conductivity often frustrates its wider applications in many fields. Nanotechnology has provided new insights into the development of functional nanomaterials with unique chemical and physical properties. Silver has been effectively incorporated into the cotton fabrics as the antimicrobial agents due to the strong inhibitory and
\end{abstract}

antimicrobial effects on a broad spectrum of bacteria, fungi and virus with low toxicity to human being. In this review, a variety of strategies have been summarized to load silver on cotton fabrics in situ or ex situ and to fabricate high performance value-added cotton fabrics with self-cleaning, UV protection, electric conductivity and antimicrobial capability depending on the synthesis of silver coating or silver-based nanocomposite coating.

Chongjun Huang, Yurou Cai are equally contributed.

C. Huang · Y. Cai · X. Chen · Y. Ke $(\varangle)$

Department of Biomedical Engineering, Key Laboratory

of Biomaterials of Guangdong Higher Education

Institutes, College of Life Science and Technology, Jinan

University, 510632 Guangzhou, China

e-mail: lisa6863@163.com 


\section{Graphic abstract}

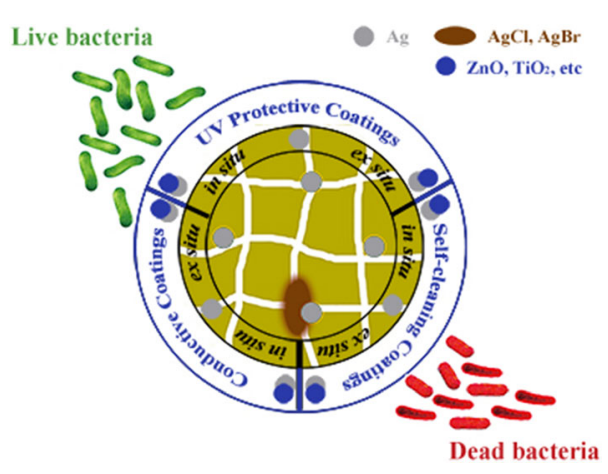

Keywords Cotton · Antimicrobial - Self-cleaning · UV protection · Electric conductivity · Coating

\section{Introduction}

Cellulose, consisted by thousands of glucose units, is the most abundant natural polysaccharide. As one of the most important cellulose fibers, cotton is widely used as sportswear, healthcare and medical textiles due to its excellent properties including biodegradability, hygroscopicity, flexibility, breathability, good skin affinity and low cost. However it is easily wrinkled and soiled with other characteristics such as low strength and UV-protective capability. More importantly, cotton is a favorable media for microbial growth under certain humidity and temperature, causing discoloration, mechanical strength loss, foul odor and even negative health effects to human body. Modification of cotton fabrics with antimicrobial agents has become a popular way to produce high performance value-added textiles (Nadi et al. 2018; Morais et al. 2016).

Organic antibacterial agents, such as quaternary ammonium salts and $N$-halamines (Liu et al. 2013), polypyrrole (Varesano et al. 2009), tetramethylcyclosiloxyl-piperazin tetra guanidine (Wei et al. 2019), ketoconazole (Hedayati et al. 2020) and phenolic compounds (Hong 2015), have been used to modify cotton fabrics through a pad-dry-cure process. The modified cotton possessed high sterilization ability and good color fastness, however some antimicrobial agents showed poor heat and hydrolysis resistance. Antimicrobial peptide is a novel antimicrobial agent with higher specific activity and good biocompatibility. Incorporating these peptides into polyelectrolyte multilayer coating provided the decorated gauzes with strong antimicrobial activity for both $S$. aureus and $K$. pneumonia (Gomes et al. 2015). Antimicrobial peptides were immobilized on alkyl ketene dimer-modified cellulose nanofibers via a immersion process, producing an antimicrobial surface against $B$. subtilis (Gonzalez et al. 2017). This physical method would avoid the structural destruction of the peptides to protect their antimicrobial activity, but the weak binding strength often leads to their rapid release, which is a main concern for fabricating durable antimicrobial cotton fabrics. High cost of the antimicrobial peptides would limit their use to medical applications either.

Recent advances in nanotechnology have provided new insights into antimicrobial agents, and led to the development of functional nanomaterials with unique chemical and physical properties. Antimicrobial nanoparticles (NPs) have been effectively incorporated into the fabrics (Zhang et al. 2016; Shahid-ulIslam et al. 2016; Emam 2019), among which silver (Ag) has attracted great attention because of its low toxicity and surface plasmon resonance features along with the strong inhibitory and antimicrobial effects on a broad spectrum of bacteria (Liao et al. 2019; Burduşel et al. 2018). $\mathrm{Ag}, \mathrm{AgX}(\mathrm{X}=\mathrm{Cl}$ or $\mathrm{Br})$ or $\mathrm{Ag} / \mathrm{Cu}$ nanocomposite coated fabric have been reported to present good antifungal properties against C. albicans or Aspergillus niger (Ilic et al. 2009a, b; Rehan et al. 2018; Paszkiewicz et al. 2016; Klemencic et al. 2014). In 2020, Coronavirus disease 2019 spread quickly around the world and has been infecting tens of millions of people. As therapeutic antiviral agents, $\mathrm{Ag}$ or Ag-based nanocomposites fight the drugresistant types of virus, and their potential interaction with virus (e.g. coronavirus) has been summarized by Han D et al. (2020). Ag NPs possessed inhibiting effect on influenza A virus H1N1 (Miao and Zheng 2010), and their nanocomposites with chitosan exhibited antiviral activity against H1N1 either (Mori et al. 2013). Ag NPs presented the lethal concentration 50 and 90 of 34.88 and $64.56 \mathrm{mg} / \mathrm{ml}$, respectively against fourth instar mosquito larvae of the Zika virus vector Aedes aegypti (Ishwarya et al. 2017). $\mathrm{Ag}_{2} \mathrm{O} / \mathrm{AgO}$ NPs indicated a reduction rate of $49.23 \%$ in cytopathic effect against Herpes Simplex virus (El-Sheekh et al. 2020). Ag/chitin sheets showed much stronger 
antimicrobial properties against influenza A virus, and the antiviral capability enhanced with the increase in Ag NPs content (Nguyen et al. 2014). Yacaman MJ et al. have demonstrated that Ag NPs undergo a sizedependent interaction with HIV-1, for nanoparticles exclusively in the range of $1 \sim 10 \mathrm{~nm}$ attached to the virus. Ag NPs interacted with the HIV-1 virus via preferential binding to the gp120 glycoprotein knobs, thus inhibiting the virus from binding to host cells (Elechiguerra et al. 2005). More studies have been focused on the antimicrobial capability of $\mathrm{Ag}$ or $\mathrm{Ag}$ based nanocomposites, and the number will increase dramatically with the urgent demand on antimicrobial medical supplies.

It is postulated that the antimicrobial activity is derived from the adhesion to the microbial cells and experiences a series events: alters the structure and function of microbial membrane, generates reactive oxygen species and free-radicals, and inactivates the essential proteins and genes. The microbial signaltransduction pathways are finally changed by the microorganisms. Generally, the antimicrobial activity of AgNPs was mainly influenced by their morphology, size, surface charge, concentration and colloidal states (Akter et al. 2018; Durán et al. 2016). Cotton should immobilize more antimicrobial agents to ensure bactericidal effect throughout the life of the fabrics, however, large quantities of the leached silver may exert serious risk to the environment. Acquisition of an ideal antimicrobial durability with a small loading of silver and a minor damage to the bulk properties of fabrics is a substantial challenge.

High performance value-added fabrics have been designed to endow multi-functionalities to cotton fabrics including self-cleaning, UV protection, electric conductivity, and antimicrobial capability as well. Self-cleaning feature has two meanings: superhydrophobic property and photo superhydrophilic property. The former route is to fabricate superhydrophobic surfaces to repel water so that spherical water droplets can clean dirt particles by an easy roll-off mechanism; the latter focuses on photocatalytic degradation of dyes. A sequential deposition of branched poly(ethylenimine), Ag NPs and fluorinated decylpolyhedral oligomeric silsesquioxane (FPOSS) was applied on cotton fabrics to obtain antibacterial and superhydrophobic surface with a water contact angle of $\sim 169^{\circ}$ and a sliding angle of $\sim 3^{\circ}$. The superhydrophobic coating prevented
AgNPs leaching during laundry because water cannot seep through the coating, while F-POSS allowed the release of $\mathrm{Ag}^{+}$(Wu et al. 2016). Ag NPs decorating cotton are sensitive to light, but their low quantum yields due to the high rate of the electron-hole recombination and low visible-light activity hinder the practical application for self-cleaning fabrics. Ag NPs coating possessed UV protective properties due to absorption and reflection of UV radiation (Rehan et al. 2015). Ag deposition on cotton fabrics endows a conductive and high electromagnetic interference (EMI) shielding coating. Ag coated carbon fabric with a compact and continuous layer via an electroless plating method using glucose as a reducing reagent presented a volume resistivity of $8.99 \times 10^{-4} \Omega$.cm (Chen et al. 2017). Ag-based nanocomposites with $\mathrm{ZnO}, \mathrm{TiO}_{2}$ and reduced graphene oxides have shown great promise to fabricate high performance valueadded fabrics with enhanced self-cleaning, UV protection, electric conductivity and antimicrobial capability.

In this work, a variety of strategies have been reported to immobilize $\mathrm{Ag}$ on cotton to fabricate antimicrobial fabrics in situ or ex situ, depending on whether the nanoparticles are synthesized and deposited simultaneously on the fabric or not. Factors that influence the loading efficiency of nanoparticles and their binding fastness with textiles were discussed in order to achieve durable antimicrobial cotton fabrics without sacrifice the bulk properties. High performance value-added fabrics with other multi-functionalities such as self-cleaning, UV protection and electric conductivity via immobilization of $\mathrm{Ag}$ or Ag-bearing nanocomposites were also been reviewed briefly.

\section{Silver decorated cotton fabric via $e x$ situ route}

Decoration of silver ex situ on cotton fabrics is an easy approach via incorporating silver salts, silver nanoparticles and even monomeric silver-organic compound complexes directly (Table 1). Thanks to the weak adhesion of antimicrobial agents to the fabric, the antimicrobial cotton presents a rapid release with increasing number of washing cycles, thus resulting in unsatisfied laundering durability. Moreover, silver releasing from the antimicrobial cotton has potential risks to the environment and human health, since its 
Table 1 Antibacterial cotton fabrics based on $\mathrm{AgNO}_{3}$ and $\mathrm{Ag}$ NPs

\begin{tabular}{|c|c|c|}
\hline Technique & Microbe & Ref \\
\hline \multicolumn{3}{|l|}{ Ex situ dipping in $\mathrm{AgNO}_{3}$ solution } \\
\hline \multicolumn{3}{|l|}{ Using crosslinking agents } \\
\hline $\begin{array}{l}\text { Carboxymethylcellulose } \\
\text { hydrogels/fumaric acid }\end{array}$ & S.aureus, E. coli, & Bozaci et al. (2015); \\
\hline $\begin{array}{l}\text { Acryloyl sulfadiazine-methyl } \\
\text { methacrylate copolymers/ethylene } \\
\text { glycol diglycidyl ether }\end{array}$ & $\begin{array}{l}\text { K.pneumonia, } \\
\text { MRSA,VRE }\end{array}$ & Cao et al. (2013) \\
\hline \multicolumn{3}{|l|}{ Pre-treated fabrics with compounds } \\
\hline Monochlorotrizinyl $\beta$-cyclodextrin & S. aureus, E. coli & Ibrahim et al. (2018); \\
\hline $\begin{array}{l}\text { Pre-treated fabrics with } \mathrm{O}_{2} \text { or } \mathrm{N}_{2} \\
\text { plasma }\end{array}$ & S. aureus & Shahidi et al. (2010) \\
\hline \multicolumn{3}{|l|}{ Ex situ Dipping in Ag NPs suspension } \\
\hline None pre-treatment & $\begin{array}{l}\text { F. oxysporum, } \\
\text { A. brassicicola, } \\
\text { S. aureus, E. coli }\end{array}$ & $\begin{array}{l}\text { Vankar and Shukla (2012); } \\
\text { Perelshtein et al. (2008) }\end{array}$ \\
\hline \multicolumn{3}{|l|}{ Using polymer network coating } \\
\hline Gum tragacanth & S. aureus, E. coli & Ranjbar-Mohammadi (2018) \\
\hline \multicolumn{3}{|l|}{ Using crosslinking agents } \\
\hline 1,2,3,4-Butanetetracarboxylic acid & S. aureus, E. coli & Montazer et al. (2012a); \\
\hline $\begin{array}{l}\beta \text {-Cyclodextrin grafted polyacrylic acid/ } \\
\text { ephichlorphydrin }\end{array}$ & & $\begin{array}{l}\text { Hebeish et al. (2011); } \\
\text { El-Rafie et al. (2013); }\end{array}$ \\
\hline Citric acid & & El-Rafie et al. (2010) \\
\hline \multicolumn{3}{|c|}{ Pre-treated fabrics or Ag NPs with compound/polymer } \\
\hline Carboxymethyl chitosan & S. aureus, E. coli, & Xu et al. (2018b); \\
\hline $\begin{array}{l}\text { Acidic mixture including mercaptoacetic } \\
\text { acid, acetic anhydride, acetic acid and } \\
\text { concentrated sulfuric acid }\end{array}$ & K. pneumoniae & $\begin{array}{l}\text { Park et al. (2012); } \\
\text { Xu et al. (2018a); }\end{array}$ \\
\hline Cysteine; Ag NPs/chitosan & & Arif et al. (2015); \\
\hline $\begin{array}{l}\text { Amino-terminated hyperbranched } \\
\text { polymer }\end{array}$ & & Zhang et al. (2009); \\
\hline Sodium periodate/sericin & & Yue et al. (2014); \\
\hline $\begin{array}{l}\text { Sodium periodate/amino-terminated } \\
\text { hyperbranched polymer }\end{array}$ & & Zhang et al. (2013) \\
\hline \multicolumn{3}{|l|}{ Using Ag NPs/polymer complexes } \\
\hline $\begin{array}{l}\text { Ag NPs/Polystyrene-block-polyacrylic } \\
\text { acid }\end{array}$ & S. aureus, E. coli & Budama et al. (2013); \\
\hline Ag NPs/DNA & & Takeshima et al. (2015) \\
\hline \multicolumn{3}{|l|}{ In situ immobilizing Ag NPs } \\
\hline \multicolumn{3}{|l|}{ Physical treatment of $\mathrm{AgNO}_{3}$} \\
\hline Argon glow discharge & S.aureus, E. coli, & Li et al. (2017a, b); \\
\hline Electron beam irradiation & B. subtilis & Chmielewska and Sartowska (2012) \\
\hline \multicolumn{3}{|c|}{ Chemical compounds reducing $\mathrm{AgNO}_{3}$ with or without binder } \\
\hline $\begin{array}{l}\text { Butylamine, }{ }_{\text {L-ascorbic, glucose/cetyl }} \\
\text { trimethyl ammonium }\end{array}$ & S. aureus, E. coli, & Lee et al. (2007); \\
\hline bromide, sodium borohydride/L-cysteine & B. subtilis, & Bacciarelli-Ulacha et al. (2014); \\
\hline $\begin{array}{l}\text { Sodium borohydride/polyacrylic acid, } \\
\text { maleic anhydride }\end{array}$ & C. albicans, & El-Shishtawy et al. (2011); \\
\hline
\end{tabular}


Table 1 continued

\begin{tabular}{|c|c|c|}
\hline Technique & Microbe & Ref \\
\hline Trisodium citrate/carboxymethyl chitosan & P. aeruginosa & $\begin{array}{l}\text { Airoudj et al. (2015); } \\
\text { Xu et al. }(2017 \mathrm{a}, \mathrm{b}) ; \\
\text { Wang et al. }(2017 \mathrm{a}, \mathrm{b})\end{array}$ \\
\hline \multicolumn{3}{|c|}{ Macromolecule reducing $\mathrm{AgNO}_{3}$ with or without binder } \\
\hline Alkali hydrolyzed alginate & S. aureus, E. coli & Zahran et al. (2014); \\
\hline Polydopamine & P. aeruginosa & Xu et al. (2011); \\
\hline $\begin{array}{l}\text { Poly }(2 \text {-aminoethyl methacrylate }) / \gamma \\
\text { irradiation }\end{array}$ & & Liu et al. (2014) \\
\hline \multicolumn{3}{|l|}{ Cellulose backbone as reducing agent } \\
\hline Reducing $\mathrm{AgNO}_{3}$ via heat reduction & S. aureus, E. coli & Jiang et al. (2011); \\
\hline Reducing Tollens' reagent & & Montazer et al. (2012a); \\
\hline $\begin{array}{l}\text { Reducing } \mathrm{AgNO}_{3} \text { under basic condition, } \\
\text { sodium hydroxide }\end{array}$ & & $\begin{array}{l}\text { Tang et al. (2013); } \\
\text { Emam et al. (2015); }\end{array}$ \\
\hline Keliab & & $\begin{array}{l}\text { Emam et al. (2016); } \\
\text { Aladpoosh et al. (2014) }\end{array}$ \\
\hline
\end{tabular}

toxicity strongly depends on the accumulated concentration (Gaillet and Rouanet 2015). The fabrics are usually pre-modified to introduce reactive groups via chemical and physical treatment to achieve stable silver immobilization. For example, the bleached cotton or mercerized cotton having negative functional groups could anchor Ag NPs, though such modification often weakens the strength of the fibers.

\section{Silver salts}

Inorganic silver salts such as silver nitrate have already been used as the antimicrobial agents since ancient Roman times, and often applied for treating cotton fabrics via sorption process (Fig. 1, Bulk sorption). Since the absorption capacity will determine the final antimicrobial activity, high dosage of silver salts is a key point for fabricating antimicrobial cotton fabric. $\beta$-cyclodextin, an eco-friendly hosting compound, increases the absorption of silver salts by its hydrophobic cavities. The cotton fabrics being grafted with monochlorotriazinyl $\beta$-cyclodextin showed an inhibition zone reducing from $27.5 \mathrm{~mm}$ ( $S$. aureus) and $24.5 \mathrm{~mm}$ (E. coli) to $21.0 \mathrm{~mm}$ and $18.0 \mathrm{~mm}$ after 10 washings (Ibrahim et al. 2018). The inclusion of Ag ions increased with the increasing concentration of $\mathrm{AgNO}_{3}$ in the finishing bath, so that the modified cotton fabrics possessed an enhanced antibacterial capability thanks to the rapid release of $\mathrm{Ag}$ ions.

Weak absorption of silver salts is a huge obstacle to fabricate antibacterial cotton fabrics via sorption process, therefore surface modification is required to improve the loading efficiency and stability of silver salts. For example, plasma-treatment of the fabric was reported to enhance the absorption of silver nitrate, and silver particles showed a decreasing size of $250 \mathrm{~nm}$ compared with $800 \mathrm{~nm}$ for the untreated cotton. Moreover, the quantity of silver particles on $\mathrm{N}_{2}$ plasma-treated fabric was greater than that on $\mathrm{O}_{2}$ plasma-treated one. The silver decorated fabrics showed $95 \%$ and $100 \%$ bacterial reduction, and the values maintained $92 \%$ and $99 \%$ after 10 consecutive home laundering for $\mathrm{O}_{2}$ and $\mathrm{N}_{2}$ plasma treated fabrics, respectively (Shahidi et al. 2010).

Coating with silver salts-polymer networks would endow antibacterial capability to the cotton fabrics without impact their bulk properties (Fig. 1, Coating). A silver nitrate-carboxymethylcellulose hydrogel using fumaric acid as a crosslinking agent was padded on the cotton, where $\mathrm{Ag}$ ions formed electrostatic bindings with negative groups of the hydrogels to produce uniformly distributed silver particles. When the padding time increased, the tensile strength of the fabrics decreased due to the acid treatment, but the whiteness did not alter substantially. The coated cotton 


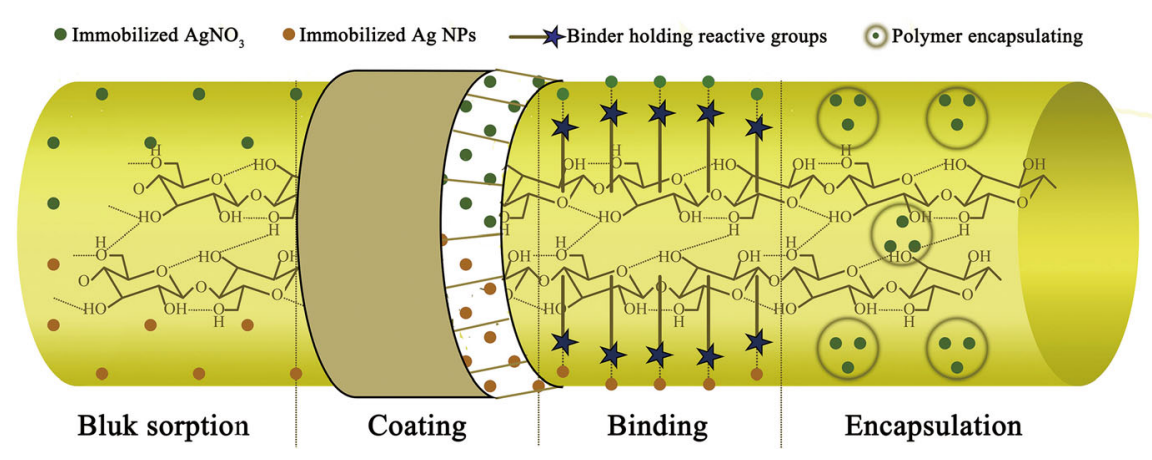

Fig. 1 Schematic illustration of fabricating silver-decorated cotton fabric via bulk sorption, coating, binding and encapsulation of silver salts or silver nanoparticles

fabrics demonstrated $99.9 \%$ reduction for both $S$. aureus and $K$. pneumonia, but only a reduction of $67.4 \%$ for $S$. aureus and $60.6 \%$ for $K$. pneumonia after 10 cycles washings for polymer solution containing $2 \times 10^{-3} \mathrm{M}$ silver, probably due to partial removal of silver nitrate (Bozaci et al. 2015).

In addition to the electrostatic bonds, coordination bonds between $\mathrm{Ag}$ ions and polymer chains enhance the stability of silver salts on cotton surface. Cao et al. (2013) modified cotton fabrics with acryloyl sulfadiazine-methyl methacrylate copolymers using ethylene glycol diglycidyl ether as a bifunctional binder (Fig. 1, Binding). The immobilized sulfadiazine moieties onto cotton formed coordination complexes with silver cations to produce polymeric silver sulfadiazines. The modified fabrics provided a $6-\log$ reduction of $10^{8}$ $\mathrm{CFU} / \mathrm{mL}$ of $S$. aureus, E. coli, methicillin-resistant $S$. aureus (MRSA) and vancomycin-resistant E. (VRE) in 30-60 min. More importantly, the sulfadiazine moieties on the modified cellulose would be transformed into silver-sulfadiazine coordination complexes again after exposure to aqueous silver nitrate. The silver content decreased from $0.58 \mathrm{wt} \%$ to 0.10 wt $\%$ after 50 washing, but could be recharged to 0.53 $w t \%$. This refreshable function avoided the depletion of antimicrobial agents, providing the cotton fabrics with durable antimicrobial ability.

It should be mentioned that silver nitrate is often limited for the application to textile materials because of its black-brown staining when exposed to the light, air or other uncontrolled reduction processes and of its low durability. Most studies performed only 10 washings for durable antibacterial tests, therefore more washing cycle is needed to evaluate the antimicrobial capability.

\section{Silver Nanoparticles}

Ag NPs are among the earliest investigated inorganic nanoparticles for their antibacterial and wound healing properties, and several such products have been already commercialized. Functioned as multifunctional agents, they impart coloration and antimicrobial properties to cotton fabrics via chemical reductants or plant extracts (Parashar et al. 2009; Kaviya et al. 2012; Bankara et al. 2010; Dipankar and Murugan 2012; Augustine et al. 2014). The latter route is costeffectiveness and eco-friendliness without using high pressure, energy, temperature or toxic chemicals. For example, cotton fabrics being treated with Ag colloid for $4 \mathrm{~h}$ showed antifungal activity against $F$. oxysporum and A. brassicicola, where Ag NPs were obtained by using aqueous extract of lemon leaves (Citrus limon) which acted as reducing agent and encapsulating cage for the nanoparticles (Vankar and Shukla 2012).

Nanoparticles agglomeration is one of the most widely acknowledged challenges compromised with macroscopic properties. Ultrasound irradiation has proven as a successful method to weaken this effect. It activated the cotton surface and facilitated the deposition and dispersion of small Ag NPs, thereby providing an enhanced antibacterial activity against E. coli and S. aureus (Perelshtein et al. 2008). Reliable finishing methodologies such as composite finishes were also employed to reduce the agglomeration of $\mathrm{Ag}$ NPs. Biodegradable gum tragacanth/Ag NPs $(\sim 20 \mathrm{~nm})$ composites were applied to fabricate an antibacterial coating (Fig. 1, Coating) by a simple pad-dry-cure method, where the gum tragacanth functioned as the chelating polymer for Ag NPs. The 
nanoparticles were distributed completely and uniformly in the gum tragacanth coating, but the authors did not show the content of Ag NPs. The strength and strain of the gum tragacanth-modified cotton increased to $45 \mathrm{MPa}$ and $91 \%$, compared with $38 \mathrm{MPa}$ and $67 \%$ of the raw cotton fabric. However, immobilization of Ag NPs did not influence the mechanical properties of the fabrics significantly (Ranjbar-Mohammadi 2018).

Nanoparticles stabilization on cotton fabric is another major concern because Ag NPs are lack of reactivity to form chemical bonds with cotton. A crosslinking agent or a binder (Fig. 1, Binding) that contains at least two functional groups bonded with $\mathrm{Ag}$ NPs and the cellulose chains has been employed to achieve the stable immobilization. The reaction of carboxylic acids with cellulose is the most common process to decorate a variety of cellulose fibre, for example, 1,2,3,4-butanetetracarboxylic acid. It bonded with cotton fabrics and provided high affinity towards the positive Ag NPs via hydroxyl and carboxyl groups. Ag NPs ( $\sim 60 \mathrm{~nm})$ colloidal treated cotton fabric showed higher bacterial reduction (>90\%) than Ag NPs trapped one ( $20 \%)$ after 30 washing cycles, though the silver content of the former fabric decreased from 1.63 to $0.89 \%$. The treated cotton fabric had higher wrinkle recovery without yellowing, and the wrinkle recovery angle increased to $150.7^{\circ}$ compared with $108.1^{\circ}$ of the untreated cotton (Montazer et al. 2012a). $\beta$-cyclodextrin grafted polyacrylic acid can serve as reducing and capping agents for $\mathrm{Ag} \mathrm{NPs}$ to control the reduction reaction. It protected the silver atoms from overgrowth and agglomeration, and obtained spherical Ag NPs with a mean size of $3 \sim 22 \mathrm{~nm}$. Cyclodextrin- $g$-polyacrylic acid treatment was reported to enhance Ag NPs content $(\sim 50 \mathrm{mg})$ on fiber surface in the presence of ephichlorphydrin (crosslinker), and the growth of $S$. aureus and E. coli was inhibited (Hebeish et al. 2011). Water soluble polysaccharides being extracted from marinemacro-algae were functioned as reducing and stabilizing agents to form spherical AgNPs with the maximum diameter of $7 \sim 20 \mathrm{~nm}$, and the cotton fabrics were treated with the Ag NPs colloidal solution at a concentration of $108 \mathrm{ppm}$ using citric acid (crosslinker) via pad/dry technique. The bacterial reduction of Ag-NPs decorated cotton fabrics reached to $100 \%$ against $S$. aureus and $E$. coli, but decreased to $87 \%$ and $83 \%$ after 10 washing, respectively (El-Rafie et al. 2013). Biomass filtrate of fungus F. solani was applied to prepare Ag NPs colloid with a size range of $3 \sim 8 \mathrm{~nm}$. Incorporation of $1 \%$ binder in AgNPs colloid finishing bath increased the bacterial reduction up to $97 \%$ and $91 \%$ for $S$. aureus and $E$. coli in very minute Ag NPs amount of $54 \mathrm{ppm}$, and remained at $94 \%$ and $85 \%$ after 20 laundering cycles, respectively, compared with $53 \%$ and $48.7 \%$ for the fabrics without the binder (El-Rafie et al. 2010). It should be noted that the application of crosslinker or binder may lead to undesirable effects for cotton fabrics or make them associated with toxicity.

Ag NPs adhesion on fabrics has been challenged due to their low charge density. Surface modification via introducing cotton with reactive functional groups would enhance the affinity of Ag NPs to the fabric through covalent bonds, electrostatic attraction or hydrogen bonds. Cotton fabrics being padded with $\mathrm{Ag} /$ carboxymethyl chitosan composite presented bacterial reduction rates of over $94 \%$ against both $S$. aureus and E. coli even after 50 consecutive laundering tests, where the primary amine groups of carboxymethyl chitosan formed a coordination bond with $\mathrm{Ag}$ ions and the carboxylic acid groups were linked covalently to cotton via an esterification with the cellulose hydroxyl groups at high temperature of $180^{\circ}$. Ag NPs $(63.9 \sim 68.2 \mathrm{~nm})$ adhered strongly to the surface so that the fabric with $12.5 \%$ loss of Ag still possessed similar vapor permeability, water absorbability, tensile breaking strength and flexibility after 50 washing tests (Xu et al. 2018b).

Grafts with thiol groups that provide the cellulose with a strong metal-sulfur bond are very effective for immobilizing Ag NPs onto the cotton surface, resulting in high deposition efficiency and low nanoparticle release. Thiol-modified cotton was achieved via dipping the fabric in acidic mixture including mercaptoacetic acid, acetic anhydride, acetic acid and concentrated sulfuric acid (Thiol-cotton), and then immersed into Ag NPs colloids via simple impregnation (Ag-thiol-cotton) where spherical Ag NPs $(10 \sim 20 \mathrm{~nm})$ were positioned at the exterior fiber via a covalent bond. The treated fabric was dark yellow while the raw cotton fabric did not show a change in color even after immersion in $\mathrm{Ag}$ NPs colloids (Ag-cotton). Ag NPs loading of Ag-cotton was $302 \mathrm{mg} / \mathrm{kg}, 120$ times lower than that of Ag-thiolcotton. Silver release from Ag-thiol-cotton was $0.008 \sim 0.024 \%, \quad 0.012 \sim 0.027 \% \quad$ and $0.097 \sim 0.186 \%$ respectively for an acidic, neutral 


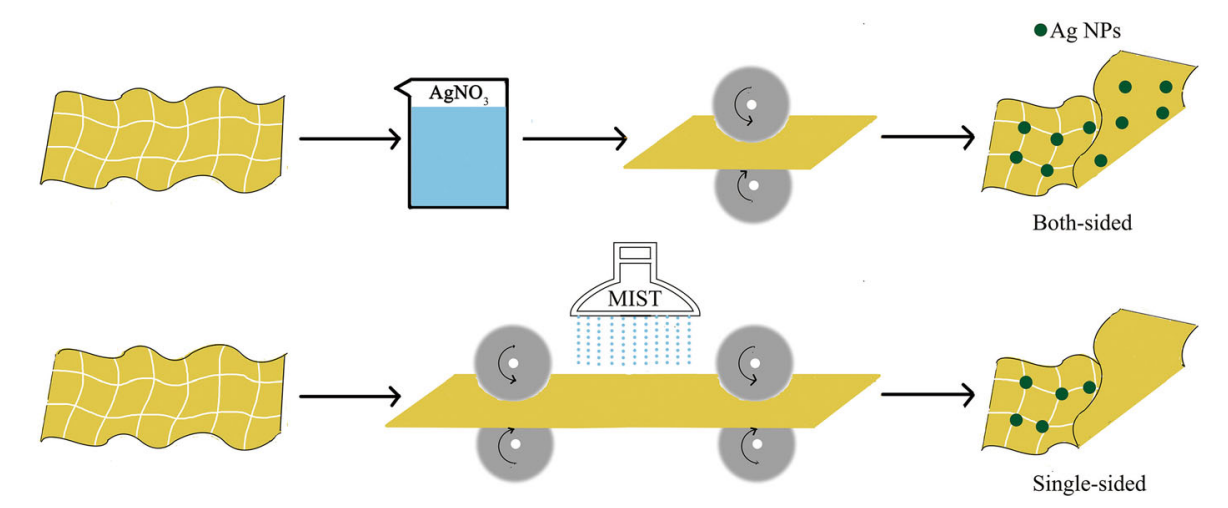

Fig. 2 Schematic illustration of the surface modification of fabrics via single-sided or both-sided technique

and basic washing, much lower than $1.98 \sim 10.9 \%$, $5.95 \sim 8.93 \%$ and $0.99 \sim 4.96 \%$ for Ag-cotton, demonstrating its higher durability in various $\mathrm{pH}$ ranges. Generally, thiol-modified fabric showed over 99.9\% growth inhibition of the microorganism (Park et al. 2012). Liu XD et al. (Xu et al. 2018a) employed a "mist" procedure to introduce Ag NPs on one side of fabrics (Fig. 2): Cotton fabric was first exposed to a cysteine mist steam (Cys-cotton) and then exposed successively to a silver nitrate mist steam and a sodium borohydride mist steam (Ag-Cys-cotton), where cysteine was linked covalently to cotton via esterification with cellulose hydroxyl groups and to Ag NPs via coordination bonds. The content of Ag NPs enhanced from 0.74 to $1.46 \mathrm{mg} / \mathrm{g}$ as the concentration of cysteine increased. Ag-Cys-cotton with silver loss of $\sim 15 \%$ still possessed bacterial reduction rates of $94 \%$ against both $S$. aureus and E. coli after 90 consecutive laundering. The authors confirmed the strong binding between Ag NPs and cysteine against abrasion forces because the size reduction of Ag NPs was consistent with the loss of silver. The vapor permeability and water absorbability of Ag-Cys-cotton decreased respectively by 10.5 and $2.8 \%$ compared with raw cotton fabrics, however the breaking strength and the elongation did not change significantly. Different from the pad-dry-cure technique, this mist procedure provided a route for fabricating single-sided antibacterial coating for cotton fabric. More importantly, the tailored thickness may decrease the release of silver without sacrifice the durable antibacterial ability.

Modification of AgNPs is another way to introduce strong bonding with cotton fabrics to enhance laundering durability. AgNPs ( $\sim 27 \mathrm{~nm}$ in diameter) being produced by reducing silver nitrate with sodium citrate were decorated with chitosan via a simple immersion method (CS-Ag), where chitosan was functioned as chelating agents for numerous metal ions to increase total positive charge density, resulting an increase in destruction of cell membranes negatively charged. An aqueous solution containing CS-Ag and other auxiliaries was then padded onto the cotton fabrics (CS-Agcotton). The modified cotton possessed the bacterial reduction rates of $99.01 \%$ and $98.78 \%$ for $S$. aureus and E. coli, and reduced to $98.95 \%$ and $85.82 \%$ after 20 washes. CS-Ag-cotton presented an increased tensile strength in warp direction but a decrease in weft direction, and there was no significant difference on the whiteness and absorbency between CS-Agcotton and raw cotton fabrics (Arif et al. 2015). Dendrimers and hyperbranched polymers with numerous interior cavities as well as inward and outward oriented functional groups have also be utilized as templates to control the synthesis of Ag NPs with small size, good monodispersity and stability. Aminoterminated hyperbranched polymer was an effective self-reducing and stabilizing agent to produce Ag NPs $(10 \sim 30 \mathrm{~nm})$ without agglomeration, and the colloids could be stored steadily more than two months because of a large amount of polymer being adsorbed on Ag NPs. The cotton fabric was immersed in Ag NPs colloids with silver content ranging from $20 \mathrm{mg} / \mathrm{l}$ to $200 \mathrm{mg} / \mathrm{l}$, where amino-terminated hyperbranched polymer served as a binder to fix Ag NPs on the fabrics to provide durable antimicrobial properties. The bacterial reduction of the treated cotton fabric reached to $99.0 \%$ (S. aureus) and $99.3 \%$ (E. coli) at silver content of $\sim 88 \mathrm{mg} / \mathrm{kg}$, and maintained over $98.8 \%$ after 20 consecutive home laundering (Zhang et al. 2009). 
Strong and stable bonding between Ag NPs and fabric is essential to ensuring the high-efficient deposition and durability without unwanted release of nanoparticles to deteriorate the fabric, therefore modification of Ag NPs along with fabrics is regarded as an effective route to strengthen the bonding greatly. For example, amino-terminated hyperbranched polymer as a reducer was used to generate stable Ag NPs colloids with an average size of $\sim 10.8 \mathrm{~nm}$ without any other stabilizer. Meanwhile, cotton fabrics was periodate-oxidized to produce aldehyde groups that would react with amino-terminated hyperbranched polymer being absorbed on Ag NPs in mild condition to provide durable antibacterial fabric. It was believed that the concentration of Ag NPs colloids was the most important factor to determine Ag NPs content on fabrics. After the cotton fabrics were treated with $10 \mathrm{mg} / \mathrm{L} \mathrm{Ag} \mathrm{NPs} \mathrm{colloid,} \mathrm{the} \mathrm{bacterial} \mathrm{reduction} \mathrm{rates}$ of the modified fabrics having $\mathrm{Ag}$ content of $149.88 \mathrm{mg} / \mathrm{kg}$ were $99.43 \%$ and $99.45 \%$ respectively for $S$. aureus and E. coli, and maintained over $96 \%$ after 50 washings with $\mathrm{Ag}$ content of $116.08 \mathrm{mg} / \mathrm{kg}$. Oxidization treatment lowered the breaking strength of cotton fabrics, and the breaking strength deceased slightly with the increasing concentration of Ag NPs. The color of Ag NPs treated cotton fabric became darker with the increase in Ag NPs content due to their surface plasmon absorption (Zhang et al. 2013). Biocompatible sericin was functioned as a reducing and dispersing agent to produce a stable $\mathrm{Ag} \mathrm{NP}_{\mathrm{S}^{-}}$ sericin colloid with no obvious precipitation and color change even after one month at ambient temperature. The hybrid colloid ( $\sim 18 \mathrm{~nm}$ ) was employed to finish the sodium periodate-modified cotton fabrics, where a cross-linking network was formed between sericin and oxidized cellulose. Ag NPs on Ag-sericin cotton was larger than that of Ag-sericin colloids, perhaps owing to Ag NPs aggregation during the finishing treatment. $\mathrm{Ag}$-sericin cotton showed bacterial reduction rates of above $99 \%$, and still reached over $95 \%$ against $S$. aureus and E. coli after 20 washings. Sericin endowed cotton fabrics relatively smooth surface and good wear ability. The whiteness of the cotton decreased from 89.70 to 78.65 after finishing. Finishing treatment did not change the breaking strength of the fabric significantly, though the breaking strength of oxidized cotton showed a declining trend with the increasing concentration of oxidant due to the degradation of cellulose (Yue et al. 2014).
Finishing treatment with an encapsulating system would enhance the stability of Ag NPs on the cotton and realize a controlled release of $\mathrm{Ag}$ ions (Fig. 1, Encapsulation). For example, polystyrene- $b$-polyacrylic acid copolymer (encapsulating polymer) being synthesized by the atom transfer free radical polymerization could form reverse micelles in toluene, among which Ag NPs around $20 \mathrm{~nm}$ were located within the cores regardless of the silver precursor ratio. Agcopolymer encapsulation padded fabrics provided stable attachment of Ag NPs onto the cotton, where an esterification reaction took place between polyacrylic acid (corona) and hydroxyl groups of cellulose. The antibacterial activity remained up to 5 washings against E. coli and 20 washings against $S$. aureus (Budama et al. 2013). DNA from salmon milt was used as templates to produce spherical Ag NPs (< $10 \mathrm{~nm}$ ) and formed a thin layer around Ag NPs core. Ag-DNA encapsulation was further immobilized onto the polycationic-modified cotton to produce antibacterial fabrics (Ag-DNA cotton), showing no colonies after $18 \mathrm{~h}$ incubation with $E$. coli for Ag-DNA cotton having Ag NPs of $30 \mathrm{ppm}$ (Takeshima et al. 2015). Encapsulation protected Ag NPs from interacting directly with fabrics physically and chemically, however, the antimicrobial activity was thus decreased at some extent.

Generally, antimicrobial activity of Ag NPs deposited fabrics is more preferable than silver salt immobilized fabrics due to its high surface area to volume ratio and the lower release of silver. Direct impregnation of Ag NPs into the fabrics is a typical route for fabricating Ag-cotton hybrids, but usually frustrated with the nanoparticles aggregation, low deposition efficiency and low adhesion affinity. Silver released rapidly from the fabric due to the weak adhesive force between silver and the cotton surface, resulting in unsatisfied laundering durability.

\section{Silver decorated cotton fabric via in situ route}

Direct immobilization of Ag NPs is often ineffective and raises environmental concerns because Ag NPs are prone to leach out during washing. Non-leaching and stable $\mathrm{Ag} /$ cotton fabric is therefore proposed via in situ route, where silver ions are firstly loaded onto the cotton fabric and then reduced to Ag NPs. The production of AgNPs consists of consecutive steps of 
classical nucleation and growth, aggregative nucleation and growth, and Ostwald ripening. In situ method promotes the stabilization efficiency of nanoparticles to lower the tendency to agglomerate and controls the size in nano scale (Table 1). Except argon glow discharge treatment (Li et al. 2017a, b) and electron beam irradiation (Chmielewska and Sartowska 2012), Ag NPs can be synthesized in situ on the fabrics by using chemical reducing agents to reduce $\mathrm{AgNO}_{3}$ in a one-bath process, such as sodium borohydride, butylamine, ${ }_{\mathrm{L}}$-ascorbic and glucose (Lee et al. 2007; Bacciarelli-Ulacha et al. 2014; ElShishtawy et al. 2011).

Cotton fabrics are often modified before chemical reducing reaction to achieve stable immobilization of Ag NPs. A grafted cysteine on cotton via esterification between its carboxylic acid groups and cellulose hydroxyl groups can form coordinate bonds between its thiol groups with Ag NPs $(\sim 63.9 \mathrm{~nm})$ in situ reduced by sodium borohydride, producing an antimicrobial fabric with bacterial reduction rates of $100 \%$ for E. coli and S. aureus and maintaining over $97 \%$ after 50 consecutive laundering cycles. Ag decorated cotton became darker while Cys-cotton showed no color change compare with the raw cotton, and presented similar vapor permeability $\left(1140 \mathrm{~g} / \mathrm{m}^{2} / \mathrm{d}\right)$, water absorption (270\%) and tensile breaking strength to the raw cotton, illustrating that immobilization of Ag NPs did not alter the bulk properties of the fabrics significantly (Xu et al. 2017a).

Plasma is very effective to introduce functional groups or produce radicals to induce graft polymerization. The cotton fabric being grafted with polyacrylic acid attracted silver nitrate through the electrostatic interaction, and Ag NPs with an average size of $17 \mathrm{~nm}$ were then formed on cotton fabrics without visible aggregation via in situ reduction by sodium borohydride (M-Ag). Plasma treatment increased capillary flow height of the fabrics, and plasma induced graft polymerization on fabrics endowed much higher capillary flow height than only plasma treatment. Different from light brown of $\mathrm{Ag}$ NPs loading cotton without plasma treatment (C-Ag), the color of M-Ag cotton changed to dark yellow, indicating higher $\mathrm{Ag}$ NPs deposition than C-Ag cotton. The degradation rate of methylene blue of $\mathrm{M}-\mathrm{Ag}$ cotton was higher than that of C-Ag cotton, and did not decrease significantly even after 3 cycles, indicating durable self-cleaning activity of $\mathrm{M}-\mathrm{Ag}$ cotton under visible light. M-Ag cotton showed good antibacterial activity, and only $5.4 \%$ reduction of the inhibition zone was shown after 30 washings. The weight loss of $\mathrm{M}-\mathrm{Ag}$ cotton was a little greater than that of the control and C-Ag cotton fabrics (Wang et al. 2017a, b). Maleic anhydride was plasma polymerized and hydrolyzed to produce carboxylic groups on the cotton fabrics. Ag ions were bonded with the fabrics and reduced by $\mathrm{NaBH}_{4}$ to form spherical Ag NPs $(\sim 8 \mathrm{~nm})$ dispersed homogeneously. A distinct inhibition zones of Ag-cotton against E. coli was nearly $41 \%$ of the sample surface (Airoudj et al. 2015).

Carboxymethyl chitosan grafted cotton could form coordination bonds between the amine groups and $\mathrm{Ag}$ NPs being reduced in situ by trisodium citrate through a mist process (mist-cotton, $45.9 \mathrm{~nm}$ ) or an immersion process (immersion-cotton, $52.8 \mathrm{~nm}$ ). Immersion-cotton possessed a more smooth and darker surface than mist-cotton thanks to the higher loading of Ag NPs. The bacterial reduction rates of mist-cotton against both $S$. aureus and E. coli remained over $95 \%$. Mistcotton had a good vapor permeability of $1138 \mathrm{~g} / \mathrm{m}^{2} / \mathrm{d}$, close to the raw cotton $\left(1140 \mathrm{~g} / \mathrm{m}^{2} / \mathrm{d}\right)$, but much higher than immersion-cotton $\left(785 \mathrm{~g} / \mathrm{m}^{2} / \mathrm{d}\right)$; a good water absorption of $265.5 \%$, almost equal to that of the raw cotton $(272.5 \%)$, much higher than immersion-cotton $(165.6 \%)$. The tensile breaking strength of mist-cotton was about $17.5 \mathrm{MPa}$, almost equal to the raw cotton, but much lower than that of immersion-cotton (22.8 MPa). It should be mentioned that mist process is very complex and might not be suitable for industrial production (Xu et al. 2017b).

Hydrophilic polymers having reductive groups were effective reducing agents for in situ synthesis of Ag NPs on cotton fabric and their hydrophilic chains also prevented proteins deposition and bacterial adhesion. For example, Ag-cotton was prepared via immersing the fabric into Ag NPs colloids being reduced by alkali hydrolyzed alginate. The silver content increased with the increasing concentration of $\mathrm{Ag}$ NPs colloids in the presence of binder, and the maximum content of $114.17 \mathrm{mg} / \mathrm{kg}$ decreased to $61.03 \mathrm{mg} / \mathrm{kg}$ after 20 washing cycles. It was found that the finishing process using $50 \mathrm{ppm}$ AgNPs colloids without a binder was sufficient to exhibit good antibacterial activity against E. coli, P. aeruginosa and $S$. aureus, and the bacterial reduction was retained $90 \%$ even after 20 washing cycles (Zahran et al. 2014). Dopamine can self-polymerize to form a 
uniform film on cotton fabric under alkaline condition, and its remaining catechol groups can reduce $\mathrm{Ag}^{+}$to $\mathrm{Ag}^{\circ}$. Monodispersed Ag NPs as well as some aggregated Ag particles with diameter of $100 \sim 300 \mathrm{~nm}$ were distributed uniformly on the fabric surface. The bacterial reduction of Ag NPs decorated cotton reached to $99.99 \%$, and did not alter remarkably after 30 consecutive laundering cycles, with a final $\mathrm{Ag}$ content decreasing to $15 \mathrm{mg} / \mathrm{g}$. In the meantime, the aggregated silver particles disappeared and only some Ag NPs with diameter of $80 \sim 90 \mathrm{~nm}$ remained (Xu et al. 2011). A pomegranate-shaped polymer structure wrapping Ag aggregations were synthesized via the coincident growth of Ag NPs and polymer chains, and the size of pomegranates structure was therefore determined by the reaction ratio of the reduction and graft polymerization. The photografted poly(2-aminoethyl methacrylate) was used as a reducing agent to form $\mathrm{Ag}$ nanoparticle aggregations up to $500 \mathrm{~nm}$ thanks to the coordination forces between amino groups and silver, and the grafting degree of $\mathrm{Ag}$ and poly(2-aminoethyl methacrylate) were $0.54 \%$ and $14.6 \%$, respectively. The pomegranates structure endowed the fabrics with an enhanced whiteness and superhydrophilicity as water drops spread out within $0.2 \mathrm{~s}$. The bacterial reduction maintained $90 \%$ after 50 accelerated laundering cycles that was equivalent to 250 instances of home laundering, with the total loss of silver below $10 \%$ (Liu et al. 2014).

More interestingly, cellulose can be used as the reducing agent to support and synthesize nano silver, and the reactivity of its hydroxyl groups and reducing ends enhanced greatly at high temperature. Ag NPs with an average size of $40 \mathrm{~nm}$ was uniformly decorated on the cotton surface when the deposition time was 10 and $30 \mathrm{~min}$, but the size increased to $100 \mathrm{~nm}$ when the deposition time prolonged to $50 \mathrm{~min}$. The modified fabrics having silver content of $0.6890 \sim 1.3561 \mathrm{mg} / \mathrm{g}$ retained the bacterial reduction of $98.5 \%$ and $94.3 \%$ against $E$. coli and $S$. aureus after 20 washings, respectively. The antibacterial activity increased slightly with the increasing concentration of $\mathrm{AgNO}_{3}$, but enhanced significantly from 23.93 to $99.99 \%$ as the temperature increased. The color difference values of Ag NPs decorated fabrics were 9.25-18.32 compared with the raw cotton as the reaction time increased from 10 to $50 \mathrm{~min}$ (Jiang et al. 2011). Tollens' reagent is a mild oxidizing agent and can reduce to nano silver particles using cellulosic chains as reducing and stabilizing agents. Spherical Ag NPs with an average size of $88 \mathrm{~nm}$ were loaded directly on the fabrics to endow over $96 \%$ of bacterial reduction rates against $S$. aureus and $E$. coli after 30 washing, where cellulose chains were oxidized to oxycellulose (Montazer et al. 2012b).

Mercerization finishing can convert crystalline structures of cotton from cellulose I to cellulose II. Under basic condition, cellulose hydroxyl groups were supposed to be activated and the silver ions were reduced to Ag NPs bound to cotton. Color strength of Ag-mercerized cotton was higher than Ag-cotton without mercerization because there were a few aggregates on Ag-cotton while Ag NPs on the mercerized cotton were uniformly distributed. As $\mathrm{pH}$ value of solution increased, silver contents of cotton did not increase, but color strength of cotton with Ag NPs enhanced and the value was twice after heating treatment. Ag NPs decorated cotton completely inhibited bacterial growth even after 7 laundering cycles no matter mercerized or not (Tang et al. 2013). Pre-alkalization treatment produced alcoholic and aldehydic groups on cotton, which reduced in situ silver ions to AgNPs with size majority (70\%) of less than $80 \mathrm{~nm}$ without any other reducing agent. As the concentration of $\mathrm{AgNO}_{3}$ increased, $\mathrm{Ag}$ content increased from 48.7 to $2391.5 \mathrm{mg} / \mathrm{kg}$ and the lightness decreased. The color strength reached to 10.32 when the concentration of silver ions was $400 \mathrm{mg} / \mathrm{L}$. The modified fabric exhibited an inhibition zone of $12 \mathrm{~mm}$ against $S$. aureus at low $\mathrm{Ag}$ content $(66.8 \mathrm{mg} / \mathrm{kg})$ and no difference in water absorption from the raw cotton (Emam et al. 2015). Two solventless techniques, sorption (S-Ag) and padding (P-Ag), were studied carefully to determine their effect on Ag-mercerized cotton. S-Ag cotton exhibited higher Ag content $(69.3 \sim 6094.8 \mathrm{mg} / \mathrm{kg})$ than P-Ag cotton (33.8 $\sim 609.3 \mathrm{mg} / \mathrm{kg}$ ) because the fabrics swelled in sodium hydroxide to expose more hydroxyl groups to absorb silver ions. When the temperature elevated from 70 to $95^{\circ} \mathrm{C}, \mathrm{Ag}$ contents increased by factor of $2 \sim 3$ for $\mathrm{P}-\mathrm{Ag}$ cotton, but did not change for $\mathrm{S}-\mathrm{Ag}$ cotton. The increase in reaction temperature had no serious effects on the color of fabrics for both techniques. Bacterial reduction and UV protection factor (UPF) reached to $99 \%$ and 12.59 for fabric with Ag content of $5912.3 \mathrm{mg} / \mathrm{kg}$, and reduced to $90 \%$ and 10.19 after 20 washings (Emam et al. 2016). 
Keliab, natural ashes containing sodium and potassium carbonate, provides an alkali environment with $\mathrm{pH}$ value of 13, where the hydroxyl groups are oxidized to ketone, aldehyde or carboxylate to reduce $\mathrm{Ag}$ ions to $\mathrm{Ag}^{\circ}$ simultaneously on the fabrics. Absorption of carbonate ions restrained the agglomeration of nanoparticles, therefore Ag NPs decorated cotton showed high bacterial reduction over $99 \%$. The color change value increased with the increasing concentration of $\mathrm{AgNO}_{3}$, but decreased slightly with the increasing concentration of Keliab because more Ag NPs were supposed to form in solution. The concentration of $\mathrm{AgNO}_{3}$ or Keliab did not influence the tensile strength and tensile strains significantly (Aladpoosh et al. 2014).

Silver decoration on cotton fabrics whenever ex situ or in situ has achieved significant improvement on antibacterial capability. Various capping agents have been employed to stabilize Ag NPs on cotton fabrics to avoid agglomeration. Polymers having strong interactions with the fabric and Ag NPs can serve as the dispersion medium and binder to achieve stable immobilization. Polymeric capping agents can also be tailored to introduce diverse functionalities such as amine or thiol groups that enable tremendous possibilities with respect to the surface functionalization of Ag NPs or fabrics. In addition, metal-fabric hybrids via electrostatic-assembly using direct impregnation or in situ reduction technique led to an efficient deposition of Ag NPs to the cellulose fabric, but nanoparticles could be easily released from the fabric under acidic or basic environments because ionic charges and bond strength were influenced by $\mathrm{pH}$ value.

\section{Ag-based nanocomposites for multi-functional coating}

Many attempts have been conducted to endow cotton fabrics with multifunctionalities, including self-cleaning, UV protection, electric conductivity and antimicrobial capability. Ag-based nanocomposites with other metal or metal oxide have been designed to fabricate high performance value-added cotton fabrics, such as antimicrobial $\mathrm{ZnO}$ (El-Nahhal et al. 2013, 2020; Selvam et al. 2012; Gao et al. 2019) or $\mathrm{TiO}_{2}$ (Doganli et al. 2016; Chitichotpanya et al. 2019; Yuranova et al. 2006). $\mathrm{CuO}$ (Ma et al. 2013;
Perelshtein et al. 2013), $\mathrm{Cu}_{2} \mathrm{O}$ (Sing et al. 2013; Sedighi et al. 2014b; Montazer et al. 2015) or Cu NPs (Xu et al. 2018c; Sedighi et al. 2014a) has also been immobilized onto the fabric to offer durable antimicrobial properties with or without binders. It has been reported that $\mathrm{Ag} / \mathrm{Cu}$ hybrid coating showed good antibacterial and antifungal activity against E. coli, $S$. aureus, MRSA, A. baumanii, $P$. aeruginosa, $P$. vulgaris and $C$. albicans (Paszkiewicz et al. 2016; Slamborova et al. 2013). $\mathrm{Ag} / \mathrm{Cu}$ nanoparticles on cotton fabric possessed a localized surface plasmon resonance (Anderson et al. 2016), and bimetallic coating with low concentration of $\mathrm{Ag} / \mathrm{Cu}$ $(0.015 \sim 0.13 \mathrm{wt} \%)$ had antimicrobial properties against a wide range of multidrug-resistant bacteria and fungi (Eremenko et al. 2016). Ag/Cu coated cotton showed higher adsorption rate of tryptophan than $\mathrm{Ag}$ coated cotton, but the complexation of tryptophan and $\mathrm{Ag} / \mathrm{Cu}$ NPs did not reduce their bactericidal capability against a number of microorganisms (Petrik et al. 2020). Ag/graphene or Ag/graphene oxide nanocomposites were doped in hydrogels using 1-hexyl-3methyl-imidazolium as dispersant to achieve the antimicrobial hybrid coating (Espinoza-Ibarra et al. 2019). Special core/shell $\mathrm{SiO}_{2} @ \mathrm{Ag}$ NPs coating provided cotton fabrics with bacterial reduction of 97.49\% (Mohamed et al. 2017).

\section{Self-cleaning coatings}

Self-cleaning cotton is classified as one of the intelligent fabrics because it is resource (water and chemicals) savings on cleaning and prolongs the lifetime of the fabrics. Self-cleaning feature is generally based on Lotus leaf effect (superhydrophobic property) or photo superhydrophilic property. Selfcleaning coatings of Ag-based nanocomposites on cotton fabrics were summarized in Table 2 .

Superhydrophobic surfaces with water contact angles above $150^{\circ}$ and sliding angles below $10^{\circ}$ can been fabricated via tuning the surface roughness and chemical composition. Due to high water repellency of the superhydrophobic surfaces, water droplets in spherical shapes can clean dirt particles by an easy roll-off mechanism. Since fabrics possess a micrometer-scale roughness originating naturally from the fibers and the corresponding woven structure, a singlescale nanostructure needs to be formed to lower the surface free energy with an aim at reducing bacterial 
Table 2 Self-cleaning coatings of Ag-based nanocomposites on cotton fabrics

\begin{tabular}{|c|c|c|c|}
\hline Treatment of fabric & Microbe & Functions & Ref \\
\hline $\begin{array}{l}\text { Dipped sequentially with branched } \\
\text { poly(ethylenimine), Ag NPs and fluorinated } \\
\text { decylpolyhedral oligomeric silsesquioxane }\end{array}$ & $\begin{array}{l}\text { E.coli, } \\
\text { B. subtilis }\end{array}$ & $\begin{array}{l}\text { Water contact angle of } \sim 169^{\circ} \text { and a } \\
\text { sliding angle of } \sim 3^{\circ} ; \\
\text { Enhanced the color fastness to washing } \\
\text { and rubbing; } \\
\text { Retained antibacterial ability of AgNPs/ } \\
\text { PEI-coated fabrics }\end{array}$ & $\begin{array}{l}\text { Wu et al. } \\
\text { (2016) }\end{array}$ \\
\hline $\begin{array}{l}\text { Synthesized } \mathrm{TiO}_{2} \text { by titanium tetrachloride/heat } \\
\text { treatment; Prepared } \mathrm{AgBr}-\mathrm{TiO}_{2} \text { via } \mathrm{TiO}_{2} \mathrm{NPs} \text { and } \\
\mathrm{AgNO}_{3} / \mathrm{KBr} \text {; Coated } \mathrm{AgBr}-\mathrm{TiO}_{2} \text { on fabric in silane } \\
\text { solution }\end{array}$ & E. coli & $\begin{array}{l}\text { Water contact angle of } 145.8^{\circ} ; \\
\text { Bacterial reduction ratio of } 99.87 \%\end{array}$ & $\begin{array}{l}\text { Rana et al. } \\
\text { (2016) }\end{array}$ \\
\hline $\begin{array}{l}\text { Modified fabric by in situ polymerization of dopamine } \\
\text { hydrochloride; Prepared Ag doped cotton through } \\
\text { immersing dopamine modified fabric in } \mathrm{AgNO}_{3} / \\
\text { glucose; Prepared } \mathrm{Cu} \text { layer by immersing } \mathrm{Ag} \text { doped } \\
\text { cotton into Fehling B/formaldehyde; Nanoneedles of } \\
\text { cupper hydroxide formed in sodium hydroxide/ } \\
\text { ammonium persulfate }\end{array}$ & -- & Water contact angle of $168^{\circ}$ & $\begin{array}{l}\text { Belal et al. } \\
\text { (2020) }\end{array}$ \\
\hline $\begin{array}{l}\text { Synthesized } \mathrm{TiO}_{2} \text { nanowire by hydrothermal treatment } \\
\text { of } \mathrm{TiO}_{2} \mathrm{NPs} \text {; Photo-reduced } \mathrm{Ag} \text { ions to } \mathrm{Ag} \text { metal on } \\
\text { the } \mathrm{TiO}_{2} \text { nanoparticles or nanowires; Coated } \mathrm{Ag} / \\
\mathrm{TiO}_{2} \text { nanocomposites on PVP treated cotton fabrics }\end{array}$ & $\begin{array}{l}\text { P. aeruginosa, } \\
\text { S. aureus, } \\
\text { E. coli, } \\
\text { B. cereus, } \\
\text { C. albicans }\end{array}$ & $\begin{array}{l}\text { Methylene blue stain on } \mathrm{Ag} / \mathrm{TiO}_{2}-\mathrm{PVP} \\
\text { treated fabric completely degraded after } \\
12 \mathrm{~h} \text { exposure to direct sunlight; } \\
\text { Good bacterial and fungi inhibition }\end{array}$ & $\begin{array}{l}\text { Hebeish } \\
\text { et al. } \\
(2013)\end{array}$ \\
\hline $\begin{array}{l}\mathrm{ZnO} \text { coated fabric via immersed in zinc nitrate } \\
\text { hexahydrate/polyallylamine solution; Immersed } \\
\mathrm{ZnO} \text { coated fabric in } \mathrm{AgNO}_{3} \text { solution }\end{array}$ & $\begin{array}{l}\text { S. aureus, } \\
\text { P. aeruginosa }\end{array}$ & $\begin{array}{l}\text { Degraded completely RhB within } 2.5 \mathrm{~h} \\
\text { under visible light; } \\
\text { RhB degradation activities maintained up } \\
\text { to } 5 \text { cycles; } \\
\text { Color stain on fabric completely removed } \\
\text { after sunlight exposure for } 15 \mathrm{~h} \text {; } \\
\text { Complete reduction in viability for } S \text {. } \\
\text { Aureus and } P \text {. Aeruginosa after } 4 \text { and } \\
6 \text { h, respectively }\end{array}$ & $\begin{array}{l}\text { Manna et al. } \\
\text { (2015) }\end{array}$ \\
\hline $\begin{array}{l}\text { Photoreduction of } \mathrm{Ag}^{+} \text {on } \mathrm{ZnO} \text {; Loaded } \mathrm{Ag} / \mathrm{ZnO} \text { and } \\
\text { stabilized on cotton fabric }\end{array}$ & - & Decolorized safranin $\mathrm{O}$ within $225 \mathrm{~min}$ & $\begin{array}{l}\text { Oda et al. } \\
\text { (2016) }\end{array}$ \\
\hline $\begin{array}{l}\text { Dipped amylase treated cotton fabric into } \mathrm{ZnAc} / \\
\mathrm{AgNO}_{3} \text { solution; Added Keliab dropwise and heated } \\
\text { at } 90{ }^{\circ} \mathrm{C}\end{array}$ & $\begin{array}{l}\text { S. aureus, } \\
\text { E. coli }\end{array}$ & $\begin{array}{l}\text { Methylene blue degradation factor } \triangle \mathrm{E} \text { of } \\
53.6 \text {; } \\
\text { Bacterial reduction of } 93.5 \% \text { and } 99.7 \% \text {, } \\
\text { respectively for } S . \text { aureus and E. coli }\end{array}$ & $\begin{array}{l}\text { Aladpoosh } \\
\text { and } \\
\text { Montazer } \\
(2016)\end{array}$ \\
\hline $\begin{array}{l}\text { Grafted MAPS onto cotton fabric via } \gamma \text { irradiation; } \\
\text { In situ deposition of } \mathrm{Ag} @ \mathrm{ZnO} \text { by zinc acetate/ } \\
\mathrm{AgNO}_{3}\end{array}$ & $\begin{array}{l}\text { E. coli, } \\
\text { S. aureus }\end{array}$ & $\begin{array}{l}\text { Methylene blue degradation reached to } \\
98 \% \text { and remained } 97 \% \text { after } 5 \text { rounds; } \\
\text { Inhibition zone of } 5.3 \mathrm{~mm} \text { and } 5.8 \mathrm{~mm} \\
\text { against } E \text {. coli and } S . \text { aureus }\end{array}$ & $\begin{array}{l}\text { Wang et al. } \\
\text { (2019) }\end{array}$ \\
\hline $\begin{array}{l}\text { Prepared } \mathrm{TiO}_{2} \text { hydrosol via tetrabutyl titanate/ } \\
\text { isopropanol; Coated cotton fabric in } \mathrm{TiO}_{2} \text { hydrosol/ } \\
\text { heat treatment; } \mathrm{Ag} / \mathrm{AgCl} \text { coating by silver nitrate/ } \\
\mathrm{HCl} \text { and } \mathrm{UV} \text { irradiation }\end{array}$ & - & $\begin{array}{l}\text { Removed methyl orange after } 60 \mathrm{~min} \\
\text { irradiation }\end{array}$ & $\begin{array}{l}\text { Wu et al. } \\
\text { (2013) }\end{array}$ \\
\hline $\begin{array}{l}\text { Dipped fabric into tetrabutyl titanate/tert-butanol and } \\
\text { acetic acid; Immersed the treated fabric in aqueous } \\
\text { AgBr; Hydrothermal treatment at } 150{ }^{\circ} \mathrm{C}\end{array}$ & - & $\begin{array}{l}\text { Complete decoloration of methylene blue } \\
\text { within } \sim 90 \mathrm{~min} \text {; } \\
\text { DMMP degradation of } 95.5 \% \text { under } \\
\text { visible light for } 2 \mathrm{~h}\end{array}$ & $\begin{array}{l}\text { Boufi et al. } \\
\text { (2019) }\end{array}$ \\
\hline
\end{tabular}


Table 2 continued

\begin{tabular}{|c|c|c|c|}
\hline Treatment of fabric & Microbe & Functions & Ref \\
\hline $\begin{array}{l}\text { Preparing } \mathrm{Ag} / \mathrm{AgCl} / \mathrm{ZIF}-8 \text { via deposition- } \\
\text { photoreduction method using } \mathrm{AgNO}_{3} \text {, } \mathrm{ZIF} \text { and } \\
\mathrm{ZnCl}_{2} \text {; Coating } \mathrm{Ag} / \mathrm{AgCl} / \mathrm{ZIF}-8 \text { on cotton; } \\
\text { Immersing the cotton fabric into tetrabutyl titanate, } \\
\text { tertbutylacohol and acetic acid }\end{array}$ & - & $\begin{array}{l}\text { Degradation of methylene blue reached } \\
98.5 \% \text { within } 105 \text { min under visible } \\
\text { light; } \\
\text { Degradation capacity maintained } \sim 85 \% \\
\text { after } 3 \text { cycles }\end{array}$ & $\begin{array}{c}\text { Guan et al. } \\
\text { (2019) }\end{array}$ \\
\hline
\end{tabular}

colonization and introducing self-cleaning properties simultaneously. Therefore, nanoparticles coating on the fabrics with a micro/nano-scale structure is an effective way to produce superhydrophobic surfaces. For example, $\mathrm{AgBr} / \mathrm{TiO}_{2}$ nanocomposites coating on cotton fabrics using silane coupling agents exhibited a contact angle of $145.8^{\circ}$ similar to the silane coated cotton and showed bacterial reduction of $99.87 \%$ against E. Coli (Rana et al. 2016). Superhydrophobic fabrics have also been designed via in situ growth of both metallic nanocrystals and transition-metal oxides through neutralization reaction and oxidation-reduction reaction. The coating with nanocrystals (such as $\mathrm{Fe}, \mathrm{Co}, \mathrm{Ni}, \mathrm{Cu}$ and $\mathrm{Ag}$ ) not only presented multiscale roughness but also coordinated with n-octadecyl thiol on the cotton fabrics, producing a superhydrophobic surface with a water contact angle of $\sim 150^{\circ}$ (Wang et al. 2013). Aligned nanoneedles of copper hydroxide on Ag-dopamine hydrochloride decorating cotton created a hydrophobic surface with a water contact angle of $168^{\circ}$, where the doped Ag NPs prevented the formation of $\mathrm{CuO}$. $\mathrm{Cu}$ NPs being formed on the fabrics were successively oxidized into nanoneedles by persulfate in the alkaline medium (Belal et al. 2020).

Photocatalytic self-cleaning coating via Ag-based nanocomposites has attracted much attention for fabricating multifunctional cotton fabrics. Photocatalysts such as $\mathrm{TiO}_{2}$ and $\mathrm{ZnO}$ NPs possess photocatalytic activity thanks to their sensitivity to UV radiation, but the photogenerated electron-hole pairs are likely to recombine. Based on the surface plasmon resonance of $\mathrm{Ag}$ NPs, $\mathrm{Ag} / \mathrm{TiO}_{2}$ or $\mathrm{Ag} / \mathrm{ZnO}$ heterostructure lowers the recombination of the electron-hole pairs along with enhancing sensitivity to visible-light. $\mathrm{Ag} / \mathrm{TiO}_{2}$ decorated fabrics that were formed via depositing $\mathrm{TiO}_{2}$ film and Ag NPs alternatively via ultrasonic treatment degraded Rhodamine $6 \mathrm{G}$ completely within 180 min under UV light (Ge et al. 2019). $\mathrm{TiO}_{2}$ nanowires were reported to be more efficient in photodegradation than $\mathrm{TiO}_{2}$ nanoparticles. Methylene blue stain on $\mathrm{TiO}_{2}$ nanowires/Ag/polyvinylpyrrolidone treated cotton fabric was completely disappeared after $12 \mathrm{~h}$ exposure to sunlight. Moreover, $2 \% \mathrm{TiO}_{2}$ nanowires/Ag nanocomposites showed inhibition zones of 24, 18, 19, 24 and $16 \mathrm{~mm}$ against $P$. aeruginosa, S. aureus, E. coli, B. cereus and $C$. albicans, respectively (Hebeish et al. 2013). Ag/ $\mathrm{ZnO}$ coating was prepared via reducing zinc salt on cotton fabrics using polyallylamine, followed by the immobilization of Ag NPs. The modified fabrics degraded rhodamine B completely within $2.5 \mathrm{~h}$ under visible light, and maintained almost similar photocatalytic activities up to 5 cycles. Color stain on $\mathrm{Ag} / \mathrm{ZnO}$ coated fabric removed completely after sunlight exposure for $15 \mathrm{~h}$, while the stain on the raw fabric did not change. $\mathrm{Ag} / \mathrm{ZnO}$ decorated fabrics showed a $100 \%$ reduction for $S$. aureus and $P$. aeruginosa after 4 and $6 \mathrm{~h}$, respectively (Manna et al. 2015). Cotton fabric being loaded with $\mathrm{Ag} / \mathrm{ZnO}$ nanocomposites that were prepared by photo-reduction of $\mathrm{Ag}^{+}$on $\mathrm{ZnO}$ nanoparticles decolorized safranin $\mathrm{O}$ within $225 \mathrm{~min}$. Photocatalytic degradation was found to be dependent on light intensity, concentration and initial $\mathrm{pH}$ value of dye solution (Oda et al. 2016). A simple exhaustion method based on zinc acetate dehydrate, $\mathrm{AgNO}_{3}$ and Keliab was employed to synthesize nanocomposites coating on cotton fabric, followed by dehydrolysis of $\mathrm{Ag}_{2} \mathrm{O}$ on $\mathrm{ZnO}$ surface to produce star-like $\mathrm{Ag} / \mathrm{ZnO}$. $\mathrm{Ag} / \mathrm{ZnO}$ coating showed the degradation factor $\triangle \mathrm{E}$ of 53.6 for methylene blue, and bacterial reduction of $93.5 \%$ and $99.7 \%$, respectively for $S$. aureus and E. coli (Aladpoosh and Montazer 2016). It is well known that $\mathrm{Ag} / \mathrm{ZnO}$ heterostructure enhances the photodegradation activity under visible-light, but $\mathrm{Ag}$ NPs can be easily oxidized by $\mathrm{ZnO}$ due to their high chemical reactivity. $\mathrm{Ag} / \mathrm{ZnO}$ modified cotton fabric 
was formed via radiation-induced graft polymerization of $\gamma$-methacryloxypropyl trimethoxysilane, followed by in-situ formation of $\mathrm{ZnO}$ and $\mathrm{Ag}$ NPs simultaneously. The grafted chains formed $\mathrm{Zn}-\mathrm{O}-\mathrm{Si}$ in the interfacial layer to increase the bonding strength of fabrics with $\mathrm{Ag} / \mathrm{ZnO} \mathrm{NPs}$, thus enhancing the nearfield amplitudes of the localized surface plasmon resonance. The photocatalytic degradation rate of the modified cotton was up to $98 \%$ and remained approximately $97.6 \%$ after 5 photocatalytic test cycles, illustrating its photocorrosion resistance, photostability and laundering durability (Wang et al. 2019).

$\mathrm{Ag} / \mathrm{AgX}(\mathrm{X}=\mathrm{Cl}$ or $\mathrm{Br})$ heterostructure is a valuable visible-light-response photocatalyst. Upon light irradiation, the photocatalyst absorbs a photon that is separated efficiently into an electron and a hole. The electrons are transferred to the surface of $\mathrm{Ag} \mathrm{NP}$ farthest away from the $\mathrm{Ag} / \mathrm{AgCl}$ interface. The holes are shifted to the surface of $\mathrm{AgCl}$ particle to oxidize $\mathrm{Cl}^{-}$ions to $\mathrm{Cl}^{\circ}$ atoms, the powerful oxidizing agents to decompose methyl orange (MO) dye into $\mathrm{CO}_{2}$ and $\mathrm{H}_{2} \mathrm{O}$ (Fig. 3). AgCl coating can be synthesized simply by exposing the fabrics to silver nitrate and sodium chloride successively (Potiyaraj et al. 2007), and an AgCl-based hybrid coating showed a $94 \%$ bacterial reduction even after 10 washings (Tomsic et al. 2009; Klemencic et al. 2012). Ag/AgCl modified cotton via using polydopamine as adhesive agent and reducing agent displayed a photocatalytic activity of $95 \%$ for C.I. RB-19 dye within $180 \mathrm{~min}$, approximately 31 times higher than those of the raw cotton, where $\mathrm{O}^{2-}$ and $\mathrm{h}^{+}$were confirmed to be the active species in the photo-degradation process (Ding et al. 2018). Combination of $\mathrm{TiO}_{2}$ and plasmonic $\mathrm{Ag} / \mathrm{AgX}$ junction is a promising approach to boost the photocatalytic activity by extending the response to the visible domain and decreasing the recombination of electron-hole pairs. $\mathrm{Ag} / \mathrm{AgCl}$ was introduced on $\mathrm{TiO}_{2}$ coated cotton by immersed the fabric in silver nitrate $/ \mathrm{HCl}$, followed by $\mathrm{UV}$ irradiation. $\mathrm{MO}$ stains on $\mathrm{Ag} / \mathrm{AgCl} / \mathrm{TiO}_{2}$ coated fabric was almost removed after $60 \mathrm{~min}$ irradiation under visible light, while the photodegradation over $\mathrm{TiO}_{2}$ coating was very weak (Wu et al. 2013). Cotton fabric being modified with $\mathrm{TiO}_{2} / \mathrm{Ag} / \mathrm{AgBr}$ layer via sol-gel route degraded Rhodamine completely in $1.5 \mathrm{~h}$ and $95.5 \%$ dimethyl methylphosphonate in $2 \mathrm{~h}$ of irradiation under visible light (Boufi et al. 2019).

Many photocatalysts have been integrated to form heterostructures to enhance the photocatalytic self-

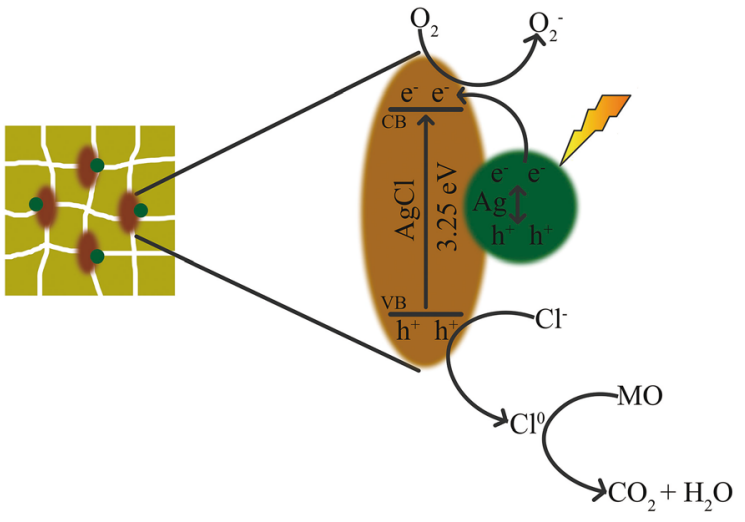

Fig. 3 Schematic mechanism of the photocatalytic reaction of $\mathrm{Ag} / \mathrm{AgCl}$ heterostructure on methyl orange dye

cleaning properties. ZIF-8, one of metal-organic framework materials, possesses characteristics of large pore size, high surface area and good thermal stability, and has be employed as a UV photocatalyst with low efficiency of exciton generation. Nanocomposites integrating $\mathrm{Ag} / \mathrm{AgCl}$ and $\mathrm{TiO}_{2}$ with $\mathrm{ZIF}-8$ were decorated on the cotton fabric to enhance absorption capacity both in ultraviolet region and visible region. The degradation rate of methylene blue by $\mathrm{Ag} / \mathrm{AgCl} /$ $\mathrm{ZIF}-8 / \mathrm{TiO}_{2}$ decorated fabric reached to $98.5 \%$ within $105 \mathrm{~min}$ irradiation under visible light, and the degradation capacity maintained approximately $85 \%$ after 3 cycles. Moreover, the first-order kinetic constant of photocatalytic degradation was $0.0332 \mathrm{~min}^{-1}$. It was suggested that. $\mathrm{OH}$ and. $\mathrm{O}_{2}{ }^{-}$ were the main active species for the degradation of methylene blue in the presence of $\mathrm{Ag} / \mathrm{AgCl} / \mathrm{ZIF}-8$ / $\mathrm{TiO}_{2}$ decorated cotton (Guan et al. 2019).

\section{UV protective coatings}

UV protective coating on the fabrics can prevent bodies from UV radiation via absorption and reflection (Table 3). Many inorganic UV absorbers, such as $\mathrm{ZnO}$ or $\mathrm{TiO}_{2}$, have been employed to fabricate UV protective coating. High reflection of UV radiation provided Ag coated fabrics with strong UV protective properties (Rehan et al. 2015), and the UV blocking capability was influenced by size and morphology of the nanoparticles (Fig. 4). Carboxymethyl celluloseAg NPs $(\sim 18.2 \mathrm{~nm})$ composite coating was reported to decreased the UV transmission radiation to 7-10\% after applying ten composite layers (Ahmed and 
Emam 2016). Macromolecules in nanocomposites coating facilitated the dispersion of UV blocking nanoparticles and reduced the total reflection of UV light because the irregular and multiple reflection of UV light on the macromolecule-Ag interface enhanced the photons absorption greatly.

$\mathrm{ZnO}$ NPs has an excellent UV blocking property over a board range of UV wavelengths with a wide direct band gap (3.37 eV) and large excitation binding energy (60 meV). Cotton fabric being loaded with Ag/ $\mathrm{ZnO}$ that spherical $\mathrm{Ag}(\sim 15 \mathrm{~nm})$ was doped on rodlike $\mathrm{ZnO}(\Phi 30 \mathrm{~nm} \times 170 \mathrm{~nm})$ had a lower UV transmittance than the raw fabric $(\sim 99 \%)$, and the UV transmission decreased with the increasing dosage of nanocomposites. Water contact angle of $\mathrm{Ag} / \mathrm{ZnO}$ laden fabric was $139^{\circ}$ higher than $103^{\circ}$ of $\mathrm{ZnO}$ laden fabric. $3 \% \mathrm{Ag} / \mathrm{ZnO}$ modified fabrics promoted the antibacterial rates to $91 \%, 96 \%$ and $98 \%$, respectively against $S$. aureus, E. coil and C. albicans, and presented anti-mildew effect of 0 grade against $A$. flavus (Gao et al. 2020). $\mathrm{Ag} / \mathrm{ZnO}$ coating with different color possessed higher UPF values of 267 (yellow), 269 (scarlet) and 274 (blue) than 179 of $\mathrm{ZnO}$ coating. As far as the antimicrobial activity, $\mathrm{Ag} / \mathrm{ZnO}$ treated fabrics exhibited $100 \%$ reduction for both $S$. aureus and $E$. coli, while $\mathrm{ZnO}$ treated fabric exhibited $75 \%$ reduction of $S$. aureus and $90 \%$ reduction for E. coli (Avazpour et al. 2017). Ag/ZnO nanocomposites $(10 \sim 35 \mathrm{~nm})$ being modified with 3-glycidyloxypropyltrimethoxysilane (GPTMS) and tetraethoxysilane (TEOS) could form an organic/ inorganic hybrid sol with chitosan via hydrolysis and condensation, where Si-OH of TEOS and GPTMS reacted with hydroxyl at C-6 position of chitosan and condensation of two $\mathrm{Si}-\mathrm{OH}$ groups formed $\mathrm{Si}-\mathrm{O}-\mathrm{Si}$ network. This hybrid sol coating provided cotton fabrics with high UV absorption (Fig. 4) and antimicrobial activity (Busila et al. 2015). A uniform and continuous $\mathrm{Ag} / \mathrm{ZnO}$ layer containing $\mathrm{Ag}, \mathrm{ZnO}$ and $\mathrm{Ag} /$ $\mathrm{ZnO}$ NPs was formed on cotton fabric via in situ reduction of zinc 2-ethylhexylcarbamate and silver 2-ethylhexylcarbamate by 3-mercaptopropyl triethoxysilane and 3-aminopropyl triethoxysilane, and presented UV blocking properties and antibacterial performance against $S$. aureus and E. coli (Kim et al. 2018). The cotton fabrics being deposited with $\mathrm{Ag}$ and $\mathrm{ZnO}$ nanoparticles $(30 \sim 120 \mathrm{~nm})$ simultaneously by an amino terminated hyperbranched polymer (reducer) under microwave irradiation enhanced UPF value to 60 compared to that of 4.79 for the raw fabric. The bacterial reduction rates against $S$. aureus and E. coli reached to $99.99 \%$, however $\mathrm{Ag}$ content decreased from $0.389 \mathrm{mg} / \mathrm{g}$ to $0.213 \mathrm{mg} / \mathrm{g}$ after 30 consecutive laundering tests (Zhang et al. 2014).

$\mathrm{Ag} / \mathrm{TiO}_{2}$ loaded cotton that was produced by successive deposition of flower-like $\mathrm{TiO}_{2}$ micronanoparticles via hydrothermal method and in situ reduction of $\mathrm{AgNO}_{3}$ exhibited UPF value of 56.39 and bacterial inhibition rates higher than $99 \%$ against $S$. aureus and E. coli ( $\mathrm{Li}$ et al. 2017a, b). Ag/TiO 2 coating on cotton fabric being formed in the presence of alanine and methyl alcohol presented bacterial reduction of $99.9 \%$ and UPF rating of $50+$ after 10 washings, where alanine on the surface of $\mathrm{TiO}_{2} \mathrm{NPs}$ was bound with $\mathrm{Ag}$ ions (Milosevic et al. 2014). Ag doped $\mathrm{TiO}_{2}$ coating on cotton fabric with very low silver concentration $(<100 \mathrm{ppm})$ via a hydrothermal deposition approach did not cause color change but developed good UV protection (UPF $>60$ ) and antibacterial activity against $S$. aureus and E. coli (Mishra and Butola 2017). The cotton fabrics being colored with yellow, red and blue reactive dyes were reported to increase the adhesion of $\mathrm{Ag} / \mathrm{TiO}_{2}$ nanocomposite, and the silver content on the dyed fabrics ranged from 65.67 to $142.24 \mathrm{mg} / \mathrm{kg}$ compared with blank fabrics of $35.05 \mathrm{mg} / \mathrm{kg}$. Ag/ $/ \mathrm{TiO}_{2}$ decorated fabrics showed an enhanced UPF with the increasing concentration of reactive dye, and remained UV protective properties even after repetitive washings (Gorjanc and Sala 2016). Ag/ $/ \mathrm{SiO}_{2}$ doped $\mathrm{TiO}_{2}$ coating via a solvothermal method achieved UPF rating of $50+$ even after 5 washings and presented low transmission values of $0.1 \%$ and $0.3 \%$ at UVA region from 315 to $400 \mathrm{~nm}$ before and after washing, respectively (Onar et al. 2011).

\section{Conductive coatings}

Conductive textiles has elicited considerable attention in biomedical devices, energy conversion, storage and electromagnetic interference shielding. High conductivity is usually related to high absorption and reflection of electromagnetic wave, therefore, optimizing the distribution of conductive fillers is a key point to achieve high conductive and electromagnetic attenuation coating. Modification of cotton fabrics is often required to enhance the binding strength of coatings, more importantly, hydrophobic treatment is 
Table 3 UV protective coatings of Ag-based nanocomposites on cotton fabrics

\begin{tabular}{|c|c|c|c|}
\hline Treatment of fabric & Microbe & Functions & Ref \\
\hline $\begin{array}{l}\text { In situ reduced } \mathrm{AgNO}_{3} \text { by trisodium } \\
\text { citrate }\end{array}$ & E. coli & $\begin{array}{l}\text { Reduction of UV transmittance of } 90 \% \text {; } \\
\text { Bacterial reduction rate of } 98 \% \text { after } 20 \text { washing cycles }\end{array}$ & Rehan et al. (2015) \\
\hline $\begin{array}{l}\text { Reduced } \mathrm{AgNO}_{3} \text { by carboxymethyl } \\
\text { cellulose; Padded Ag-carboxymethyl } \\
\text { cellulose composite via layer by layer } \\
\text { technique }\end{array}$ & E. coli & $\begin{array}{l}\text { UPF value of } 3.92 \text { at } \mathrm{Ag} \text { content of } 3.31 \mathrm{~g} / \mathrm{kg} \text { for } 10 \text { layers } \\
\text { compared to } 2.85 \text { for untreated cotton; } \\
\text { Total bacterial reduction for } 6-10 \text { layers }\end{array}$ & Ahmed and Emam (2016) \\
\hline $\begin{array}{l}\text { Prepared } \mathrm{Ag} / \mathrm{ZnO} \text { nanorods via zince } \\
\text { acetate/silver nitrate; Coated } \mathrm{Ag} / \mathrm{ZnO} \\
\text { on cotton fabric and heat treatment }\end{array}$ & $\begin{array}{l}\text { S. aureus, } \\
\text { E. coil, } \\
\text { C. albicans }\end{array}$ & $\begin{array}{l}\text { Water contact angle reached to } 139^{\circ} \text {; } \\
\text { Antibacterial rate of } 91 \sim 96 \% \text { and antifungal rate of } 98 \%\end{array}$ & Gao et al. (2020) \\
\hline $\begin{array}{l}\text { Ag colloids prepared via silver nitrate/ } \\
\text { trisodium citrate dehydrate/sodium } \\
\text { borohydride; } \mathrm{Ag} / \mathrm{ZnO} \text { nanocomposite } \\
\text { prepared via adding zinc oxide to } \mathrm{Ag} \\
\text { colloids; Coated } \mathrm{Ag} / \mathrm{ZnO} \\
\text { nanocomposite onto cotton fabric }\end{array}$ & $\begin{array}{l}\text { S. aureus, } \\
\text { E. coli }\end{array}$ & $\begin{array}{l}\text { UPF values of } 267,269 \text { and } 274 \text { for yellow, blue and scarlet } \\
\text { nanocomposite; } \\
\text { Total Bacterial reduction }\end{array}$ & Avazpour et al. (2017) \\
\hline $\begin{array}{l}\mathrm{Ag} / \mathrm{ZnO} \text { NPs }(10 \sim 35 \mathrm{~nm}) \\
\text { functionalized with GPTMS and } \\
\text { TEOS; Prepared hybrid sol via } \\
\text { suspending functionalized Ag: } \mathrm{ZnO} \\
\text { NPs in chitosan/acetic acid; Padded } \\
\text { hybrid sol onto fabrics }\end{array}$ & $\begin{array}{l}\text { E. coli, } \\
\text { S. aureus, } \\
\text { M. luteus }\end{array}$ & $\begin{array}{l}\text { UV absorption at } 367 \text { and } 420 \mathrm{~nm} \text { corresponding to } \mathrm{Ag} \text { and } \\
\mathrm{ZnO} \text {; } \\
\text { Antimicrobial activity of reducing up to } 50 \sim 95 \% \text { viability }\end{array}$ & Busila et al. (2015) \\
\hline $\begin{array}{l}\text { In situ deposited } \mathrm{Ag} \text { and } \mathrm{ZnO} \\
\text { nanoparticles via microwave } \\
\text { treatment/amino terminated } \\
\text { hyperbranched polymer (reducing } \\
\text { agent) }\end{array}$ & $\begin{array}{l}\text { S. aureus, } \\
\text { E. coli }\end{array}$ & $\begin{array}{l}\text { UPF value of } 60 \text { compared to } 4.79 \text { of untreated fabric; } \\
\text { Bacterial reduction reached to } 99.99 \%\end{array}$ & Zhang et al. (2014) \\
\hline $\begin{array}{l}\text { Deposited fabrics with flower-like } \mathrm{TiO}_{2} \\
\text { micro-nanoparticles via hydrothermal } \\
\text { deposition; In situ reduction of } \\
\mathrm{AgNO}_{3}\end{array}$ & $\begin{array}{l}\text { S. aureus, } \\
\text { E. coli }\end{array}$ & $\begin{array}{l}\text { UPF value of } 56.39 ; \\
\text { Inhibition rate higher than } 99 \%\end{array}$ & Li et al. $(2017 a, b)$ \\
\hline $\begin{array}{l}\text { Prepared } \mathrm{TiO}_{2} \text { via acidic hydrolysis of } \\
\mathrm{TiCl}_{4} \text {; Coated cotton fabric in } \mathrm{TiO}_{2} \\
\text { colloid/alanine; Immersed in } \mathrm{AgNO}_{3} \\
\text { under UV irradiation }\end{array}$ & $\begin{array}{l}\text { S. aureus, } \\
\text { E. coli }\end{array}$ & $\begin{array}{l}\text { UPF rating } 50+\text { even after } 10 \text { washing cycles; } \\
\text { Bacterial reduction of } 99.9 \%\end{array}$ & Milosevic et al. (2014) \\
\hline $\begin{array}{l}\text { Deposited } \mathrm{TiO}_{2} \text { on cotton fabric using } \\
\text { titanium tetra isopropoxide; Ag } \\
\text { deposition on } \mathrm{TiO}_{2} \text { decorated cotton } \\
\text { fabric by hydrothermal treatment }\end{array}$ & $\begin{array}{l}\text { S. aureus, } \\
\text { E. coli }\end{array}$ & $\begin{array}{l}\text { UV protection with UPF over } 60 \text {; } \\
\text { Bacterial reduction of } 99.5 \% \text { against } E \text {. coli and } 97.6 \% \text { against } \\
\text { S. aureus }\end{array}$ & Mishra and Butola (2017) \\
\hline $\begin{array}{l}\text { Pre-treated fabrics with reactive dyes; } \\
\text { Loading } \mathrm{Ag} / \mathrm{TiO}_{2} \text { nanocomposite }\end{array}$ & - & $\begin{array}{l}\text { Higher UPF for } \mathrm{Ag} / \mathrm{TiO}_{2} \text { fabrics; } \\
100 \% \text { Bacterial reduction even after } 10 \text { consecutive laundering } \\
\text { cycles; } \\
\text { Ag content on dyed cotton fabrics of } 65.67 \text { to } 142.24 \mathrm{mg} / \mathrm{kg} \\
\text { compared with blank dyeing fabrics of } 35.05 \mathrm{mg} / \mathrm{kg}\end{array}$ & Gorjanc and Sala (2016) \\
\hline $\begin{array}{l}\text { Nanosol prepared from } \mathrm{AgNO}_{3} / \\
\text { titanium isopropoxide/tetraethyl } \\
\text { orthosilicate; Coating process }\end{array}$ & S. aureus & $\begin{array}{l}\text { UPF of } 50+\text { UPF before and after washing } 5 \text { times; } \\
\text { Bacterial reduction of over } 90 \%\end{array}$ & Onar et al. (2011) \\
\hline
\end{tabular}




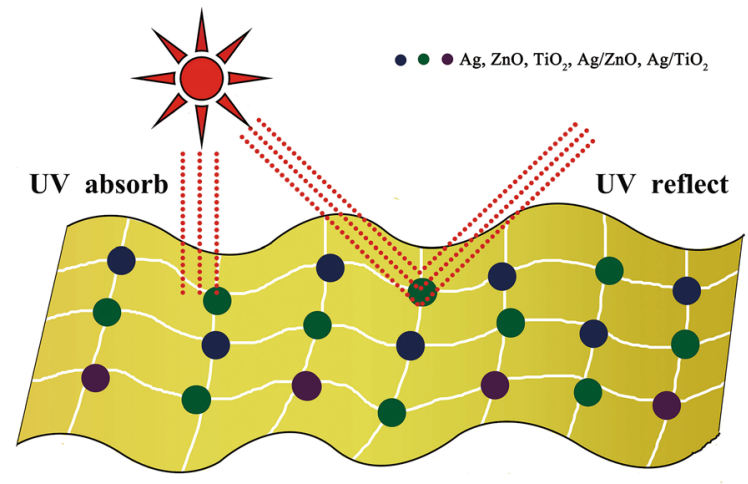

Fig. 4 Schematic mechanism of UV protective coating via absorbing or reflecting

essential to fabricating conductive coating of metal and metal oxide nanoparticles because the electrical properties are influenced by relative humidity. Conductive coatings of $\mathrm{Ag}$-based nanocomposites on cotton fabrics were summarized in Table 4 .

A conductive fabric was prepared via padding 3-mercaptopropyltriethoxysilane modified cotton with silver 2-ethylhexylcarbamate/methanol, followed by a thermal reduction process at $130{ }^{\circ} \mathrm{C}$. Ag NPs with a size of $20 \sim 100 \mathrm{~nm}$ endowed the fabrics with electric resistance as low as $3.92 \Omega$ and inhibition zones of $22.0 \mathrm{~mm}$ and $21.2 \mathrm{~mm}$ against $E$. coli and $S$. aureus, respectively (Kwak et al. 2015). Ag-epoxy coating had the shielding effectiveness (SE) of $50-69 \mathrm{~dB}$ in the frequency of $60-15000 \mathrm{MHz}$, and the concentration of precursor (silver nitrate) had a significant effect on the electromagnetic shielding effectiveness of fabrics (Perumalraj et al. 2011). Ag coated cotton with the conductivity of $\sim 3333 \mathrm{~S} / \mathrm{m}$ via a wet electroless deposition method possessed EMI SE of $\sim 111 \mathrm{~dB}$ at the plating time of $3 \mathrm{~min}$, far more than that of $30 \mathrm{~dB}$ for commercial fabrics. Moreover, $\mathrm{Ag}$ plating fabrics maintained high EMI SE by suffering dozens of washing times or one thousands of bending times (Tan et al. 2018). Core-shell yarns with conductive copper as core and cotton fiber as sheath were weaved into conductive fabrics, and spherical Ag NPs $(30 \sim 50 \mathrm{~nm})$ were coated onto the fabrics. Agmodified fabric presented a $20 \sim 55 \%$ increase of electromagnetic shielding in 500-12000 MHz to that of the untreated copper core yarn fabrics (Perumalraj and Narayanan 2014).

Bimetallic deposition of $\mathrm{Cu}$ and $\mathrm{Ag}$ over cotton fabric was a simple method for fabricating superhydrophobic textiles with electrical conductivity and antibacterial activity. $\mathrm{Cu}$ plating $\mathrm{Ag}$-deposited fabrics $(\mathrm{Cu} / \mathrm{Ag})$ possessed good electrical conductivity and EMI SE to make lightweight and flexible smart electronic fabric, where Ag-coated fabrics were treated with the electroless $\mathrm{Cu}$ plating bath containing $\mathrm{CuSO}_{4}$, glyoxylic acid (reducing agent), ethylene diamine tetraacetic acid (complexing agent) and bipyridyl (stabilizer). Surface resistivity of Ag-deposited fabrics was $\sim 620 \Omega$ and decreased to $20 \Omega$ after $\mathrm{Cu}$ electroless plating while the value of the fabric by conventional $\mathrm{Cu}$ electroless plating (control sample) was $62 \Omega$, and EMI SE of $\mathrm{Cu} / \mathrm{Ag}$ cotton was recorded as $75.53 \mathrm{~dB}$ compared with $47.43 \mathrm{~dB}$ of control sample. Regarding Joule heating behavior, the surface temperature of $\mathrm{Cu} / \mathrm{Ag}$ cotton was $83.1{ }^{\circ} \mathrm{C}$, higher than control sample of $69.6^{\circ} \mathrm{C}$. Inhibition zones of $\mathrm{Cu} / \mathrm{Ag}$ cotton were $16.5 \mathrm{~mm}$ (S. aureus) and $13 \mathrm{~mm}$ (E. coli) and decreased to $14 \mathrm{~mm}$ and $11 \mathrm{~mm}$ after a standard washing, while those of control sample were $12 \mathrm{~mm}$ (S. aureus) and $9 \mathrm{~mm}$ (E. coli) and decreased to $10.5 \mathrm{~mm}$ and $8 \mathrm{~mm}$. $\mathrm{Cu} / \mathrm{Ag}$ cotton showed good retention of the metal layer without significant loss of electrical conductivity or antibacterial properties (Ali et al. 2020). Ag over $\mathrm{Cu}$-coated cotton fabric by electroless deposition had a sheet resistance of $0.15 \Omega$ / sq, lower than $\mathrm{Cu}$-coated cotton fabric of $1.15 \Omega / \mathrm{sq}$. Electrical conductivity of $\mathrm{Ag} / \mathrm{Cu}$ coated cotton did not change significantly after two weeks, demonstrating that the bimetallic coating suppressed the oxidation of $\mathrm{Ag}$ or $\mathrm{Cu}$, and the sheet resistance remained constant during 10 washings. This bimetallic layer showed an enhanced surface roughness with water contact angles increased to $160.9^{\circ}$ and inhibition zones of $14 \mathrm{~mm}(S$. aureus) and $17 \mathrm{~mm} \mathrm{(E.} \mathrm{Coli)} \mathrm{(Suryaprabha} \mathrm{and}$ Sethuraman 2017). Electroless plating has been used to deposit continuous and uniform coatings on cotton with complex shapes, but there is still some key points needed to be handled such as controllable plating rate and interface bonding strength.

Graphene (G) and reduced graphene oxides (rGO) have characteristics of high surface area, conductivity, flexibility and stability towards thermal or chemical environment, and their composites with metal oxide or metal nanoparticles ameliorate the shielding efficiency synergistically. Hydrophobic Ag/rGO nanocomposites coating with a water contact angle of $135.1^{\circ}$ on cotton fabric being produced via microwave irradiation presented a surface resistance 
Table 4 Conductive coatings of Ag-based nanocomposites on cotton fabrics

\begin{tabular}{|c|c|c|c|}
\hline Treatment of fabric & Microbe & Functions & Ref \\
\hline $\begin{array}{l}\text { Electroless plating method using glucose as reducing } \\
\text { reagent }\end{array}$ & - & Volume resistivity of $8.99 \times 10^{-4} \Omega \cdot \mathrm{cm}$ & $\begin{array}{l}\text { Chen et al. } \\
\text { (2017) }\end{array}$ \\
\hline $\begin{array}{l}\text { Modified fabrics with 3-mercaptopropyl triethoxysilane; } \\
\text { Padded fabrics with silver 2-ethylhexylcarbamate/ } \\
\text { methanol and heat treatment at } 130{ }^{\circ} \mathrm{C}\end{array}$ & $\begin{array}{l}\text { S. aureus, } \\
\text { E. coli }\end{array}$ & $\begin{array}{l}\text { Electric resistance as low as } 3.92 \Omega ; \\
\text { Increasing inhibition zones of } 22.0 \mathrm{~mm} \\
\quad(\text { E. coli }) \text { and } 21.2 \mathrm{~mm}(\text { S. aureus })\end{array}$ & $\begin{array}{l}\text { Kwak et al. } \\
\text { (2015) }\end{array}$ \\
\hline Padded with silver nitrate-epoxy composite coating & - & $\begin{array}{l}\text { Shielding effectiveness of } 50-69 \mathrm{~dB} \text { in } \\
60-15,000 \mathrm{MHz}\end{array}$ & $\begin{array}{l}\text { Perumalraj } \\
\text { et al. (2011) }\end{array}$ \\
\hline Wet electroless deposition of $\mathrm{Ag}$ & - & $\begin{array}{l}\text { EMI shielding effectiveness } \\
\text { of } \sim 111 \mathrm{~dB} \text {; } \\
\text { A few dB reduction in EMI shielding } \\
\text { effectiveness after washing } 20 \text { times or } \\
\text { bending } 1000 \text { times }\end{array}$ & $\begin{array}{l}\text { Tan et al. } \\
\text { (2018) }\end{array}$ \\
\hline $\begin{array}{l}\text { Deposited } \mathrm{Ag} \text { NPs using ammonia/silver nitrate and heat } \\
\text { treatment; } \mathrm{Cu} \text { electroless plating on Ag coated fabrics }\end{array}$ & $\begin{array}{l}\text { S. aureus, } \\
\text { E. coli }\end{array}$ & $\begin{array}{l}\text { Surface resistivity of Ag-fabrics } \\
\text { of } \sim 620 \Omega \text {, and decreased to } 20 \Omega \\
\text { after } \mathrm{Cu} \text { electroless plating; } \\
\text { Inhibition zone of } 16.5 \mathrm{~mm}(S \text {. aureus }) \\
\text { and } 13 \mathrm{~mm}(\text { E. coli }) \text {, and decreased to } \\
14 \mathrm{~mm} \text { and } 11 \mathrm{~mm} \text { respectively; } \\
\text { Surface temperature of } 83.1{ }^{\circ} \mathrm{C} \text {, higher } \\
\text { than the conventional fabric of } 69.6^{\circ} \mathrm{C}\end{array}$ & Ali et al. (2020) \\
\hline $\begin{array}{l}\text { Deposited } \mathrm{Cu} \text { on cotton fabric by copper acetate/ } \\
\text { hydrazine hydrate; Immersing } \mathrm{Cu} \text {-coated fabric in silver } \\
\text { nitrate and heat treatment at } 120^{\circ} \mathrm{C}\end{array}$ & & $\begin{array}{l}\text { Water contact angle of } 160.9^{\circ} \text {; } \\
\text { Sheet resistance of } 0.15 \Omega / \mathrm{sq} \text {; } \\
\text { Inhibition zone of } 14 \mathrm{~mm}(\mathrm{~S} \text {. aureus }) \\
\text { and } 17 \mathrm{~mm}(\text { E. Coli })\end{array}$ & $\begin{array}{l}\text { Suryaprabha } \\
\text { and } \\
\text { Sethuraman } \\
(2017)\end{array}$ \\
\hline $\begin{array}{l}\text { Dipped cotton fabrics into GO suspension and microwave } \\
\text { irradiation for } 10 \mathrm{~min} \text {; Immersed GO coated fabric in } \\
\text { silver nitrate/trisodium citrate and microwave irradiation }\end{array}$ & - & $\begin{array}{l}\text { Surface resistance with } 5.61 \Omega / \mathrm{sq} \text {; } \\
\text { EMI SE more than } 40 \mathrm{~dB} \text {; } \\
\text { Water contact angle of } 135.1^{\circ}\end{array}$ & $\begin{array}{l}\text { Wang et al. } \\
(2017 \mathrm{a}, \mathrm{b})\end{array}$ \\
\hline $\begin{array}{l}\text { Synthesized } \mathrm{Ag} \text { decorated } \mathrm{rGO} \text { sheets by in situ } \\
\text { hydrothermal reduction of } \mathrm{AgNO}_{3} \text {; Coating } \mathrm{Ag} / \mathrm{rGO} \text { by } \\
\text { using PVP as non-ionic polymer adhesive }\end{array}$ & E. coli & $\begin{array}{l}\text { EMI shielding effectiveness of } 27.36 \mathrm{~dB} \\
\text { in } 8.2-12.4 \mathrm{GHz} \text {; } \\
\text { Inhibition zone of } 1.0 \mathrm{~cm} \text { compared } \\
\text { with } \sim 0.1 \mathrm{~cm} \text { of only GO coated } \\
\text { fabric }\end{array}$ & $\begin{array}{l}\text { Ghosh et al. } \\
\text { (2019) }\end{array}$ \\
\hline $\begin{array}{l}\text { Modified with rGO thin film by a dipping method via GO/ } \\
\text { hydrazine hydrate; Coated with Ag via magnetron } \\
\text { sputtering }\end{array}$ & - & Average surface resistance is $2.71 \Omega / \mathrm{sq}$ & He et al. (2018) \\
\hline Inkjet printing cotton fabric & - & Sheet resistance lower to $\sim 2.11 \Omega / \mathrm{sq}$ & $\begin{array}{l}\text { Karim et al. } \\
\text { (2019) }\end{array}$ \\
\hline
\end{tabular}

of $5.61 \Omega / \mathrm{sq}$, while Ag coated or rGO coated fabrics showed poor electrical conductivity, perhaps owing to the high nanoparticles deposition of $\mathrm{Ag} / \mathrm{rGO}$ $\left(3.20 \mathrm{mg} / \mathrm{cm}^{2}\right)$ coating than $\mathrm{Ag}\left(1.92 \mathrm{mg} / \mathrm{cm}^{2}\right)$ or $\mathrm{rGO}\left(0.08 \mathrm{mg} / \mathrm{cm}^{2}\right)$ coating. Surface resistance of $\mathrm{Ag} /$ rGO coating increased to $33.60 \Omega /$ sq after a washing, such high electrical conductivity made temperature of $\mathrm{Ag} / \mathrm{rGO}$ coated cotton increase to $61.3{ }^{\circ} \mathrm{C}$ when exposed to a voltage of $4 \mathrm{~V}$. Ag/rGO coated cotton possessed EMI SE of $>40 \mathrm{~dB}$ at the frequencies from 1 to $18 \mathrm{GHz}$, and decreased to $18 \sim 24 \mathrm{~dB}$ after washings (Wang et al. 2017a, b). Ag/rGO coating on cotton fabric using PVP as non-ionic adhesive, where Ag was doped on rGO sheets through in situ reduction of $\mathrm{AgNO}_{3}$ and $\mathrm{GO}$ via a hydrothermal treatment, possessed EMI SE of $27.36 \mathrm{~dB}$ in $8.2 \sim 12.4 \mathrm{GHz}$ 
and was conductive enough to light up a series of 57 LEDs with high intensity (Fig. 5). The inhibition zone of $\mathrm{Ag} / \mathrm{rGO}$ decorated fabric was $1.0 \mathrm{~cm}$ against E. coli, compared with GO coated fabric of $\sim 0.1 \mathrm{~cm}$, confirming the suppression of $E$. coli growth (Ghosh et al. 2019).

Conductive fabrics have been widely used to prepare flexible electronic devices. For example, Ag/ $\mathrm{G}$ coated cotton with a surface resistance of $2.71 \Omega / \mathrm{sq}$ was employed to fabricate a strain sensor to real-time monitor the finger rotation in strain range of $0 \sim 20 \%$, showing its high sensitivity, fast response and great stability. Sheet resistance of $\mathrm{Ag} / \mathrm{G}$ coated cotton increased from $13.6 \Omega / \mathrm{sq}$ to $2.58 \mathrm{k} \Omega / \mathrm{sq}$ after 20 washings, much lower than $\mathrm{G}$ coated cotton from 33.8 to $240.0 \mathrm{k} \Omega / \mathrm{sq}$. It should be noted that the continuous $\mathrm{Ag} / \mathrm{G}$ conductive network would be destroyed once the fabrics were deformed excessively ( $\mathrm{He}$ et al. 2018). Novel inkjet-print technique is considered to be very promising for fabricating conductive coating due to its excellent processing and environmental benefits, but frustrating with poor ink stability at higher concentration of graphene derivatives. Since graphene possessed better electrical conductivity than GO and $\mathrm{rGO}, \mathrm{Ag}$ /graphene nanocomposite as printing ink was designed to fabricate highly conductive coating with a sheet resistance lowered to $\sim 2.11 \Omega /$ sq. The sheet resistance was found to be depend on the number of print layers and $\mathrm{Ag} /$ graphene ratio in the formulation (Karim et al. 2019).

Nanocomposites coating have also been employed to other cellulose for fabricating multifunctional materials. $\mathrm{ZnO}$ doping on weakly ionised gaseous plasma modified cellulose fibre possessed high UPF values $(50+)$ when the fibre was plasma-treated for
$10 \mathrm{~s}$ (Gorjanc et al. 2014). Cellulose nanofiber with a $\mathrm{TiO}_{2}$ coating ( $\sim 25 \mathrm{~nm}$ in thickness) via hydrolysis was positive charged and showed $100 \%$ efficiency of capturing negative Au NPs $(\sim 5 \mathrm{~nm})$ through electrostatic interaction, demonstrating its high filtration efficiency for potential applications in filtration membrane areas (Zhang et al. 2019). Ag decorated cellulose nanocrystals having a percolated network upon solvent evaporation were electrically conductive with a high conductivity of $2.9 \times 10^{4} \mathrm{~S} / \mathrm{cm}$ (Meulendijks et al. 2017). Ag doping nano-fibrillated cellulose through dopamine binding exhibited relatively high strength, flexibility and thermal conductivity. It formed a thermal conductive pathways and showed a high in-plane thermal conductivity of $6.0 \mathrm{~W} /$ (m.K) when Ag NPs content was 2.0\%, 4 times that of the raw cellulose, illustrating potential applications as lateral heat spreaders in flexible electronic equipment (Shen and Feng 2018). Multi-walled carbon nanotube (MWCNT)/GO nanocomposites coating on cellulosic paper, where GO was used to improve MWCNTs dispersion in water media and nanocrystalline cellulose was employed as a binder for the nanocomposites, enhanced its mechanical properties and electro-conductivity up to $892 \mathrm{~S} / \mathrm{m}$ (Tang et al. 2014). Bacterial cellulose being modified successively by $\mathrm{Cu}$ and $\mathrm{ZnO}$ NPs using direct current magnetron sputtering and radio frequency reactive sputter coating techniques illustrated good UV resistance (T.UVA\% 0.16, T.UVB\% 0.07, UPF 1850.33), antistatic behavior (S.H.P 51.50, I.E. V 349.33) and reduction rates of $98.45 \%$ against $E$. coli and $98.11 \%$ of $S$. aureus (Wasim et al. 2020). Spherical $\mathrm{SiO}_{2} @ \mathrm{TiO}_{2}$ nanocomposites $(\sim 50 \mathrm{~nm})$ decorating bacterial cellulose via sol-gel process showed high photocatalytic activity of

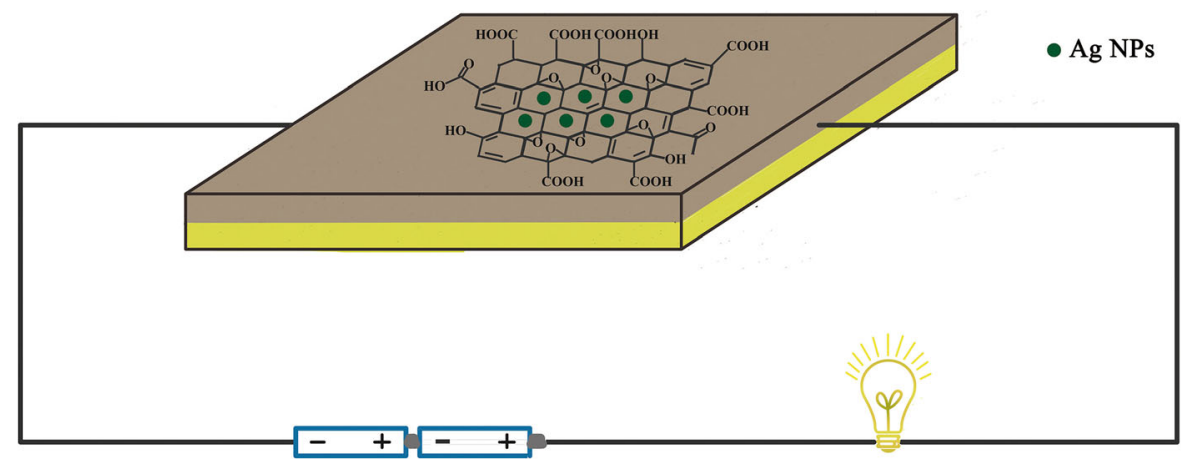

Fig. 5 Schematic illustration of $\mathrm{Ag} / \mathrm{rGO}$ conductive coating on cotton fabrics 
methyl violet $2 \mathrm{~B}$ dye in $30 \mathrm{~min}$, demonstrating its good self-cleaning performance (Monteiro et al. 2019). Photocatalytic coating on bacterial cellulose membranes through hydrolysis-polycondensation of tetraethyl orthosilicate/titanium (IV) isopropoxide and hydrothermal treatment exhibited good $\mathrm{TiO}_{2}$ dependent self-cleaning activity towards crystal violet dye. The $\mathrm{SiO}_{2}-\mathrm{TiO}_{2} / \mathrm{Ag}$ doping membranes degraded $97 \%$ dye within $50 \mathrm{~min}$ under UV illumination. More importantly, it could be easily disinfected under UV irradiation from a lamp or natural sunlight and recycled (Rahman et al. 2021). Dopamine grafted cellulose acetate membranes showed high porosity, pore size and hydrophilicity, and water permeability reached to $181.2 \mathrm{~L} / \mathrm{m}^{2} \mathrm{~h}$ with protein rejection of $93.5 \%$, showing its potential application in the field of separation (Guo et al. 2020). Cellulose carbamate containing $2.7 \sim 15.1 \% \mathrm{ZnO}$ with a hexagonal wurtzite structure displayed UV-blocking properties and antibacterial activities against $S$. aureus and E. coli. A dramatic reduction in viable bacteria was observed within $3 \mathrm{~h}$ of exposure, while all of the bacteria were killed within 6 h (Fu et al. 2015).

Nanocomposites have been decorated on cellulose to produce high performance value-added fabrics for diverse applications, but several urgent problems remained. Uncontrollable thickness of the coatings influenced the softness and wearing comfort of the fabrics. A high degree of Ag-based nanocomposites coverage on fabric surface is also a prerequisite for obtaining durable multifunctional coatings, but their toxic breakdown products and the consequent risks to human health and environment arouse great concerns and have frustrated their application in biomedical areas. Ag-nanocomposites with other nanoparticles such as $\mathrm{CuO}$ (Karlsson et al. 2008) and $\mathrm{TiO}_{2}$ (Karlsson et al. 2009) have been demonstrated their potential toxicity to cause DNA damage. However, most studies neglected important parameters such as the real content of $\mathrm{Ag}$ on fabrics and its impact on the functionalization. Over excessive loading of Ag-based nanocomposites is undesirable due to their potential toxicity, therefore, surface decoration and doping/capping treatment would be reasonable solutions.

\section{Conclusions}

- The desire for comfort, hygiene and high performance fabric has created a rapid development on multifunctional cotton. Ag-based nanocomposites endowed cotton fabrics with multifunctionalities and influenced bulk properties such as the decorative color, mechanical and comfort capability. Ag NPs presented a variety of brilliant colors because of their surface plasmon resonance, which can be tailored by changing the size and shape of AgNPs. Key decoration technologies should be mastered to balance multifunctionalities and bulk properties for developing high performance value-added cotton fabric.

- Many loading routes of $\mathrm{Ag}$ nanoparticles and nanocomposites have been reviewed in this paper. These routes should be high efficiency, economical and practical without creating ecological hazard. Most decoration ex situ and in situ were performed by using harmful chemicals which contaminate water or induce mechanical hazards to the fabric. Upon the health and environmental protection priority, green synthesis approach using nontoxic chemicals, environmentally benign solvents or renewable materials is one of the key issues that worth much consideration.

- Durable multifunctional cotton fabrics is urgently needed, and special interest is oriented toward enhancing the adherence of Ag NPs or Ag-based nanocomposites on fabrics in order to avoid low washing fastness of the coating and prevent leaching of nanocomposites into environment. Application of crosslinking agents, capping agents or binders as intermediates and pre-treatment of the fabrics or nanocomposites to increase the contents of functional groups have been summarized to improve the stability of AgNPs or Agbased nanocomposites on cotton fabrics. However, the reported $20 \sim 50$ washing cycles is insufficient for antimicrobial fabrics. Meanwhile, most studies lacked reliable data on the loading and/or releasing profile of Ag NPs or Ag-based nanocomposites. The durable antimicrobial capability and other multifunctionalities are still the biggest challenge and should be estimated accurately while taking into consideration the health and environmental problems. 


\section{Future development}

Much effort has been devoted to the development of high performance value-added cotton based on nanocomposites containing Ag NPs in order to endow the fabrics with antimicrobial capacity and selfcleaning, UV protection or electric conductivity as well. As the key functional components, Ag-based nanocomposites were essential to the durable multifunctionalities. Many studies have been focused on durable antimicrobial capability during laundry and controlled release of nanoantimicrobial agents (Rubin et al. 2018). However, few research has been done on durable self-cleaning, UV protection or electric conductivity, especially in the case of simulating surface contamination and abrasion of wearing, washing, drying and ironing in actual situation. Therefore, anti-abrasion surface with low nonspecific adhesion is potentially the critical feature for future sustainable multifunctional fabrics. Another possible study is the production of rechargable fabrics that can be recycled to integrate Ag-based nanocomposites, even if the fabrics were contaminated by the absorbed target molecules. Regarding future developments, more effort should be devoted to provide the fabrics with intelligent responsiveness, for example, response to thermal, optical or $\mathrm{pH}$ modulations. Novel visiblelight photocatalysts such as tungsten trioxide (Fan et al. 2019), Ag doped $\mathrm{TiO}_{2}$ nanotube (Van Viet et al. 2018), porphyrinic metal-organic frameworks (Nie et al. 2020), double-shell $\mathrm{Ag} / \mathrm{AgCl} / \mathrm{G}-\mathrm{ZnFe}_{2} \mathrm{O}_{4}$ nanocube (Zhang et al. 2020) have been developed in recent years, and the potential application of these photocatalysts on cotton fabrics should also be the subject of future research. Another area of research not covered yet is the employment of multifunctional cellulose to fabricate flexible electronic device. These devices using thermal conductive or electrical conductive coatings to harvest energy from body or body movement will be explored in more depth. Flexible supercapacitors is predicated as the most applicable electronic textiles with different functional agents in future perspectives.

Acknowledgments This study was financially supported by the National Natural Science Foundation of China (51572110), the Natural Science Foundation of Guangdong Province of China (2016A030313085) and the Science and Technology Planning Project of Guangdong Province of China (2015A020212025).

\section{Declarations}

Conflict of interest The author declare that he has no conflict of interest.

Informed consent Informed consent was not available as no participant is included in the study.

Human and animal rights This article does not contain any studies with human participants or animals performed by the author.

\section{References}

Ahmed HB, Emam HE (2016) Layer by layer assembly of nanosilver for high performance cotton fabrics. Fiber Polym 17:418-426. https://doi.org/10.1007/s12221-0165814-3

Airoudj A, Ploux L, Roucoules V (2015) Effect of plasma duty cycle on silver nanoparticles loading of cotton fabrics for durable antibacterial properties. J Appl Polym Sci 132:41279. https://doi.org/10.1002/APP.41279

Akter M, Sikder MT, Rahman MM, Ullah AKMA, Hossain KFB, Banik S, Hosokawa T, Saito T, Kurasaki M (2018) A systematic review on silver nanoparticles-induced cytotoxicity: Physicochemical properties and perspectives. J Adv Res 9:1-16. https://doi.org/10.1016/j.jare.2017.10. 008

Aladpoosh R, Montazer M, Samadi N (2014) In situ green synthesis of silver nanoparticles on cotton fabric using Seidlitzia rosmarinus ashes. Cellulose 21:3755-3766. https://doi.org/10.1007/s10570-014-0369-1

Aladpoosh R, Montazer M (2016) Nano-photo active cellulosic fabric through in situ phytosynthesis of star-like $\mathrm{Ag} / \mathrm{ZnO}$ nanocomposites: Investigation and optimization of attributes associated with photocatalytic activity. Carbohyd Polym 141:116-125. https://doi.org/10.1016/j.carbpol. 2016.01.005

Ali A, Baheti V, Vik M, Militky J (2020) Copper electroless plating of cotton fabrics after surface activation with deposition of silver and copper nanoparticles. J Phy Chem Solids 137:109181. https://doi.org/10.1016/j.jpcs.2019. 109181

Anderson SR, Mohammadtaheri M, Kumar D, O’Mullane AP, Field MR, Ramanathan R, Bansal V (2016) Robust nanostructured silver and copper fabrics with localized surface plasmon resonance property for effective visible light induced reductive catalysis. Adv Mater Interfaces 3:1500632. https://doi.org/10.1002/admi.201500632

Arif D, Niazi MBK, Ul-Haq N, Anwar MN, Hashmi E (2015) Preparation of antibacterial cotton fabric using chitosansilver nanoparticles. Fiber Polym 16:1519-1526. https:// doi.org/10.1007/s12221-015-5245-6

Augustine R, Kalarikkal N, Thomas S (2014) A facile and rapid method for the black pepper leaf mediated green synthesis of silver nanoparticles and the antimicrobial study. Appl Nanosci 4:809-818. https://doi.org/10.1007/s13204-0130260-7 
Avazpour S, Karimi L, Zohoori S (2017) Simultaneous coloration and functional finishing of cotton fabric using $\mathrm{Ag}$ / $\mathrm{ZnO}$ nanocomposite. Color Technol 133:423-430. https:// doi.org/10.1111/cote.12296

Bacciarelli-Ulacha A, Rybicki E, Matyjas-Zgondek E, Pawlaczyk A, Szynkowska MI (2014) A new method of finishing of cotton fabric by in situ synthesis of silver nanoparticles. Ind Eng Chem Res 53:4147-4155. https:// doi.org/10.1021/ie4011113

Bankara A, Joshi B, Kumar AR, Zinjardea S (2010) Banana peel extract mediated novel route for the synthesis of silver nanoparticles. Colloid Surface A 368:58-63. https://doi. org/10.1016/j.colsurfa.2010.07.024

Belal AS, Khalil MMA, Soliman M, Ebrahim S (2020) Novel superhydrophobic surface of cotton fabrics for removing oil or organic solvents from contaminated water. Cellulose 27:7703-7719. https://doi.org/10.1007/s10570-02003316-1

Boufi S, Abid M, Bouattour S, Ferraria AM, Conceicao DS, Ferreira LFV, Corbel G, Neto PM, Lopes PA, Vilar MR, do Rego AMB (2019) Cotton functionalized with nanostructured $\mathrm{TiO}_{2}-\mathrm{Ag}-\mathrm{AgBr}$ layer for solar photocatalytic degradation of dyes and toxic organophosphates. Int $\mathrm{J}$ Biol Macromol 128:902-910. https://doi.org/10.1016/j. ijbiomac.2019.01.218

Bozaci E, Akar E, Ozdogan E, Demir A, Altinisik A, Seki Y (2015) Application of carboxymethylcellulose hydrogel based silver nanocomposites on cotton fabrics for antibacterial property. Carbohyd Polym 134:128-135. https://doi.org/10.1016/j.carbpol.2015.07.036

Budama L, Cakır BA, Topel O, Hoda N (2013) A new strategy for producing antibacterial textile surfaces using silver nanoparticles. Chem Eng J 228:489-495. https://doi.org/ 10.1016/j.cej.2013.05.018

Burduşel AC, Gherasim O, Grumezescu AM, Mogoantă L, Ficai A, Andronescu E (2018) Biomedical applications of silver nanoparticles: An up-to-date overview. Nanomaterials 8:681. https://doi.org/10.3390/nano8090681

Busila M, Musat V, Textor T, Mahltig B (2015) Synthesis and characterization of antimicrobial textile finishing based on Ag:ZnO nanoparticles/chitosan biocomposites. RSC Adv 5:21562-21571. https://doi.org/10.1039/c4ra13918f

Cao ZB, Sun XB, Yao JR, Sun YY (2013) Silver sulfadiazineimmobilized celluloses as biocompatible polymeric biocides. J Bioact Compat Polym 28:398-410. https://doi.org/ 10.1177/0883911513490340

Chen HY, Liao F, Yuan ZY, Han XR, Xu CJ (2017) Simple and fast fabrication of conductive silver coatings on carbon fabrics via an electroless plating technique. Mater Lett 196:205-208. https://doi.org/10.1016/j.matlet.2017.03. 070

Chitichotpanya P, Inprasit T, Chitichotpanya C (2019) In vitro assessment of antibacterial potential and mechanical properties of $\mathrm{Ag}-\mathrm{TiO}_{2} / \mathrm{WPU}$ on medical cotton optimized with response surface methodology. J Nat Fibers 16:88-99. https://doi.org/10.1080/15440478.2017.1408520

Chmielewska D, Sartowska B (2012) Radiation synthesis of silver nanostructures in cotton matrix. Radiat Phys Chem 81:1244-1248. https://doi.org/10.1016/j.radphyschem. 2011.11.067
Ding K, Wang W, Yu D, Wang W, Gao P, Liu BJ (2018) Facile formation of flexible $\mathrm{Ag} / \mathrm{AgCl} /$ polydopamine/cotton fabric composite photocatalysts as an efficient visible-light photocatalysts. Appl Surf Sci 454:101-111. https://doi.org/10. 1016/j.apsusc.2018.05.154

Dipankar C, Murugan S (2012) The green synthesis, characterization and evaluation of the biological activities of silver nanoparticles synthesized from Iresine herbstii leaf aqueous extracts. Colloid Surface B 98:112-119. https:// doi.org/10.1016/j.colsurfb.2012.04.006

Doganli G, Yuzer B, Aydin I, Gultekin T, Con AH, Selcuk H, Palamutcu S (2016) Functionalization of cotton fabric with nanosized $\mathrm{TiO}_{2}$ coating for self-cleaning and antibacterial property enhancement. J Coat Technol Res 13:257-265. https://doi.org/10.1007/s11998-015-9743-7

Durán N, Durán M, de Jesus MB, Seabra AB, Fávaro WJ, Nakazato G (2016) Silver nanoparticles: A new view on mechanistic aspects on antimicrobial activity. Nanomed Nanotechnol Biol Med 12:789-799. https://doi.org/10. 1016/j.nano.2015.11.016

Elechiguerra JL, Burt JL, Morones JR, Camacho-Bragado A, Gao XX, Lara HH, Yacaman MJ (2005) Interaction of silver nanoparticles with HIV-1. J Nanobiotechnol 3:6

El-Nahhal IM, Salem J, Anbar R, Kodeh FS, Elmanama A (2020) Preparation and antimicrobial activity of ZnO-NPs coated cotton/starch and their functionalized $\mathrm{ZnO}$ $\mathrm{Ag} /$ cotton and $\mathrm{Zn}$ (II) curcumin/cotton materials. Sci Rep 10:5410. https://doi.org/10.1038/s41598-020-61306-6

El-Nahhal IM, Zourab SM, Kodeh FS, Elmanama AA, Selmane M, Genois I, Babonneau F (2013) Nano-structured zinc oxide-cotton fibers: Synthesis, characterization and applications. J Mater Sci-Mater El 24:3970-3975. https://doi. org/10.1007/s10854-013-1349-1

El-Rafie HM, El-Rafie MH, Zahran MK (2013) Green synthesis of silver nanoparticles using polysaccharides extracted from marine macro algae. Carbohyd Polym 96:403-410. https://doi.org/10.1016/j.carbpol.2013.03.071

El-Rafie MH, Mohamed AA, Shaheen TI, Hebeish A (2010) Antimicrobial effect of silver nanoparticles produced by fungal process on cotton fabrics. Carbohyd Polym 80:779-782. https://doi.org/10.1016/j.carbpol.2009.12. 028

El-Sheekh MM, Shabaan MT, Hassan L, Morsi HH (2020) Antiviral activity of algae biosynthesized silver and gold nanoparticles against Herps Simplex (HSV-1) virus in vitro using cell-line culture technique. Int $\mathrm{J}$ Environ Heal R. https://doi.org/10.1080/09603123.2020.1789946

El-Shishtawy RM, Asiri AM, Abdelwahed NAM, Al-Otaibi MM (2011) In situ production of silver nanoparticle on cotton fabric and its antimicrobial evaluation. Cellulose 18:75-82. https://doi.org/10.1007/s10570-010-9455-1

Emam HE (2019) Generic strategies for functionalization of cellulosic textiles with metal salts. Cellulose 26:1431-1447. https://doi.org/10.1007/s10570-018-21855

Emam HE, Saleh NH, Nagy KS, Zahran MK (2015) Functionalization of medical cotton by direct incorporation of silver nanoparticles. Int J Biol Macromol 78:249-256. https:// doi.org/10.1016/j.ijbiomac.2015.04.018

Emam HE, Saleh NH, Nagy KS, Zahran MK (2016) Instantly AgNPs deposition through facile solventless technique for 
poly-functional cotton fabrics. Int $\mathrm{J}$ Biol Macromol 84:308-318. https://doi.org/10.1016/j.ijbiomac.2015.12. 042

Eremenko AM, Petrik IS, Smirnova NP, Rudenko AV, Marikvas YS (2016) Antibacterial and antimycotic activity of cotton fabrics, impregnated with silver and binary silver/copper nanoparticles. Nanoscale Res Lett 11:28. https://doi.org/10.1186/s11671-016-1240-0

Espinoza-Ibarra PA, Sánchez-Valdes S, Yánez-Flores IG, Graciano-Verdugo AZ, Espinoza-Ibarra DF, Fernandez-Tavizon S, Ledezma-Pérez AS, Espinoza-Martínez AB, Rodríguez-Fernández OS, Betancourt-Galindo R, OrtegaOrtiz H, Ramirez-Vargas RR, Rodriguez-Gonzalez JA (2019) Preparation and characterization of cotton fibers coated with AA-IA hydrogel containing silver/graphene or graphene oxide nanoparticles. Polym-Plast Tech Mat 58:753-764. https://doi.org/10.1080/03602559.2018. 1520251

Fan J, Yu D, Wang W, Liu BJ (2019) The self-assembly and formation mechanism of regenerated cellulose fifilms for photocatalytic degradation of C.I. Reactive Blue 19. Cellulose 26:3955-3972. https://doi.org/10.1007/s10570-01902350-y

Fu FY, Li LY, Liu LJ, Cai J, Zhang YP, Zhou JP, Zhang L (2015) Construction of cellulose based $\mathrm{ZnO}$ nanocomposite films with antibacterial properties through one-step coagulation. ACS Appl Mater Interfaces 7:2597-2606. https://doi.org/10.1021/am507639b

Gaillet S, Rouanet JM (2015) Silver nanoparticles: their potential toxic effects after oral exposure and underlying mechanisms:a review. Food Chem Toxicol 77:58-63. https://doi.org/10.1016/j.fct.2014.12.019

Gao DG, Liu JJ, Lyu LH, Li YJ, Ma JZ, Baig W (2020) Construct the multifunction of cotton fabric by synergism between nano $\mathrm{ZnO}$ and Ag. Fiber Polym 21:505-512. https://doi.org/10.1007/s12221-020-9347-4

Gao DG, Li YJ, Lyu B, Lyu LH, Chen SW, Ma JZ (2019) Construction of durable antibacterial and anti-mildew cotton fabric based on P(DMDAAC-AGE)/Ag/ZnO composites. Carbohyd Polym 204:161-169. https://doi.org/10. 1016/j.carbpol.2018.09.087

Ge FY, Chen YM, Liu AR, Guang SY, Cai ZS (2019) Flexible and recyclable SERS substrate fabricated by decorated $\mathrm{TiO}_{2}$ film with Ag NPs on the cotton fabric. Cellulose 26:2689-2697. https://doi.org/10.1007/s10570-018-22091

Ghosh S, Ganguly S, Das P, Das TK, Bose M, Singha NK, Das AK, Das NCh (2019) Fabrication of reduced graphene oxide/silver nanoparticles decorated conductive cotton fabric for high performing electromagnetic interference shielding and antibacterial application. Fiber Polym 20:1161-1171. https://doi.org/10.1007/s12221-019-10017

Gomes AP, Mano JF, Queiroz JA, Gouveia IC (2015) Incorporation of antimicrobial peptides on functionalized cotton gauzes for medical applications. Carbohyd Polym 127:451-461. https://doi.org/10.1016/j.carbpol.2015.03. 089

Gonzalez I, Oliver-Ortega H, Tarres Q, Delgado-Aguilar M, Mutje P, Andreu D (2017) Immobilization of antimicrobial peptides onto cellulose nanopaper. Int J Biol Macromol
105:741-748. https://doi.org/10.1016/j.ijbiomac.2017.07. 094

Gorjanc M, Jazbec K, Sala M, Zaplotnik R, Vesel A, Mozetic M (2014) Creating cellulose fibres with excellent UV protective properties using moist $\mathrm{CF} 4$ plasma and $\mathrm{ZnO}$ nanoparticles. Cellulose 21:3007-3021. https://doi.org/10. 1007/s10570-014-0284-5

Gorjanc M, Sala M (2016) Durable antibacterial and UV protective properties of cellulose fabric functionalized with $\mathrm{Ag} / \mathrm{TiO}_{2}$ nanocomposite during dyeing with reactive dyes. Cellulose 23:2199-2209. https://doi.org/10.1007/s10570016-0945-7

Guan XM, Lin SJ, Lan JW, Shang JJ, Li WX, Zhan YF, Xiao $\mathrm{HY}$, Song QS (2019) Fabrication of $\mathrm{Ag} / \mathrm{AgCl} / \mathrm{ZIF}-8 / \mathrm{TiO}_{2}$ decorated cotton fabric as a highly effificient photocatalyst for degradation of organic dyes under visible light. Cellulose 26:7437-7450. https://doi.org/10.1007/s10570-01902621-8

Guo HX, Peng Y, Liu Y, Wang ZF, Hu JW, Liu JH, Ding Q, Gu JY (2020) Development and investigation of novel antifouling cellulose acetate ultrafiltration membrane based on dopamine modification. Int $\mathbf{J}$ Biol Macromol 160:652-659. https://doi.org/10.1016/j.ijbiomac.2020.05. 223

Hebeish A, El-Shafei A, Sharaf S, Zaghloul S (2011) Novel precursors for green synthesis and application of silver nanoparticles in the realm of cotton finishing. Carbohyd Polym 84:605-613. https://doi.org/10.1016/j.carbpol. 2010.12.032

Hebeish AA, Abdelhady MM, Youssef AM (2013) $\mathrm{TiO}_{2}$ nanowire and $\mathrm{TiO}_{2}$ nanowire doped Ag-PVP nanocomposite for antimicrobial and self-cleaning cotton textile. Carhohyd Polym 91:549-559. https://doi.org/10.1016/j. carbpol.2012.08.068

Hedayati N, Montazer M, Mahmoudirad M, Toliyat T (2020) Ketoconazole and Ketoconazole/ $\beta$-cyclodextrin performance on cotton wound dressing as fungal skin treatment. Carbohyd Polym 240:116267. https://doi.org/10.1016/j. carbpol.2020.116267

He S, Xin BJ, Chen ZM, Liu Y (2018) Flexible and highly conductive $\mathrm{Ag} / \mathrm{G}$-coated cotton fabric based on graphene dipping and silver magnetron sputtering. Cellulose 25:3691-3701. https://doi.org/10.1007/s10570-018-18214

Hong KH (2015) Phenol compounds treated cotton and wool fabrics for developing multi-functional clothing materials. Fiber Polym 16:565-571. https://doi.org/10.1007/s12221015-0565-0 ()

Hu YM, Lian XT, Han D (2020) On silver nano particles and silver-bearing materials as virus and bacteria killing agents. Acta Metal Sin 56:633-641. https://doi.org/10.11900/ 0412.1961.2020.00061

Ibrahim NA, El-Ghany NAA, Eid BM, Mabrouk EM (2018) Green options for imparting antibacterial functionality to cotton fabrics. Int J Biol Macromol 111:526-533. https:// doi.org/10.1016/j.ijbiomac.2018.01.013

Ilic V, Saponjic Z, Vodnik V, Molina R, Dimitrijevic S, Jovancic P, Nedeljkovic J, Radetic M (2009a) Antifungal efficiency of corona pretreated polyester and polyamide fabrics loaded with $\mathrm{Ag}$ nanoparticles. J Mater Sci 
44:3983-3990. https://doi.org/10.1007/s10853-009-3547$\mathrm{Z}$

Ilic V, Saponjic Z, Vodnik V, Potkonjak B, Jovancic P, Nedeljkovic J, Radetic M (2009b) The influence of silver content on antimicrobial activity and color of cotton fabrics functionalized with Ag nanoparticles. Carbohyd Polym 78:564-569. https://doi.org/10.1016/j.carbpol.2009.05. 015

Ishwarya R, Vaseeharan B, Anuradha R, Rekha R, Govindarajan M, Alharbi NS, Kadaikunnan S, Khaled JM, Benelli G (2017) Eco-friendly fabrication of Ag nanostructures using the seed extract of Pedalium murex, an ancient Indian medicinal plant: Histopathological effects on the Zika virus vector Aedes aegypti and inhibition of biofilm-forming pathogenic bacteria. J Photoch Photobio B 174:133-143. https://doi.org/10.1016/j.jphotobiol.2017.07.026

Jiang T, Liu L, Yao JM (2011) In situ deposition of silver nanoparticles on the cotton fabrics. Fiber Polym 12:620-625. https://doi.org/10.1007/s12221-011-0620-4

Karim N, Afroj S, Tan S, Novoselov KS, Yeates SG (2019) All inkjet-printed graphene-silver composite ink on textiles for highly conductive wearable electronics applications. Sci Rep 9:8035. https://doi.org/10.1038/s41598-019-44420-y

Karlsson HL, Cronholm P, Gustafsson J, Moller L (2008) Copper oxide nanoparticles are highly toxic: a comparison between metal oxide nanoparticles and carbon nanotubes. Chem Res Toxicol 21:1726-1732. https://doi.org/10.1021/ tx $800064 j$

Karlsson HL, Gustafsson J, Cronholm P, Moller L (2009) Size dependent toxicity of metal oxide particles-a comparison between nano- and micrometer size. Toxicol Lett 188:112-118. https://doi.org/10.1016/j.toxlet.2009.03.014

Kaviya S, Santhanalakshmi J, Viswanathan B (2012) Biosynthesis of silver nano-flakes by Crossandra infundibuliformis leaf extract. Mater Lett 67:64-66. https://doi.org/ 10.1016/j.matlet.2011.09.023

Kim JU, Gong MS, Kim JG (2018) Preparation of Ag/ZnOcoated cotton fabrics with UV-blocking and antibacterial properties. Cell Chem Technol 52:475-484

Klemencic D, Tomsic B, Kovac F, Simoncic B (2012) Antimicrobial cotton fibers prepared by in situ synthesis of $\mathrm{AgCl}$ into a silica matrix. Cellulose 19:1715-1729. https:// doi.org/10.1007/s10570-012-9735-Z

Klemencic D, Tomsic B, Kovac F, Zerjav M, Simoncic A, Simoncic B (2014) Preparation of novel fiber-silica-Ag composites: the influence of fiber structure on sorption capacity and antimicrobial activity. J Mater Sci 49:3785-3794. https://doi.org/10.1007/s10853-014-8090$\mathrm{x}$

Kwak WG, Oh MH, Gong MS (2015) Preparation of silvercoated cotton fabrics using silver carbamate via thermal reduction and their properties. Carbohyd Polym 115:317-324. https://doi.org/10.1016/j.carbpol.2014.08. 070

Lee HY, Park HK, Lee YM, Kim K, Park SB (2007) A practical procedure for producing silver nanocoated fabric and its antibacterial evaluation for biomedical applications. Chem Commun 28:2959-2961. https://doi.org/10.1039/ b703034g
Liao CZ, Li YC, Tjong SC (2019) Bactericidal and cytotoxic properties of silver nanoparticles. Int J Mol Sci 20:449. https://doi.org/10.3390/ijms20020449

Li SH, Zhu TX, Huang JY, Guo QQ, Chen GQ, Lai YK (2017a) Durable antibacterial and UV-protective Ag/TiO2@fabrics for sustainable biomedical application. Int J Nanomed 12:2593-2606. https://doi.org/10.2147/IJN.S132035

Liu H, Lv M, Deng B, Li J, Yu M, Huang Q, Fan C (2014) Laundering durable antibacterial cotton fabrics grafted with pomegranate-shaped polymer wrapped in silver nanoparticle aggregations. Sci Rep 4:5920. https://doi.org/ 10.1038/srep05920

Liu Y, Ma KK, Li R, Ren XH, Huang TS (2013) Antibacterial cotton treated with $\mathrm{N}$-halamine and quaternary ammonium salt. Cellulose 20:3123-3130. https://doi.org/10.1007/ s10570-013-0056-7

Li ZR, Meng J, Wang W, Wang ZY, Li MY, Chen T, Liu CJ (2017) The room temperature electron reduction for the preparation of silver nanoparticles on cotton with high antimicrobial activity. Carbohyd Polym 161:270-276. https://doi.org/10.1016/j.carbpol.2017b.01.020

Ma MG, Qing SJ, Li SM, Zhu JF, Fu LH, Sun RC (2013) Microwave synthesis of cellulose/ $\mathrm{CuO}$ nanocomposites in ionic liquid and its thermal transformation to $\mathrm{CuO}$. Carbohyd Polym 91:162-168. https://doi.org/10.1016/j. carbpol.2012.08.025

Manna J, Goswami S, Shilpa N, Sahu N, Rana RK (2015) Biomimetic method to assemble nanostructured Ag@ZnO on cotton fabrics: application as self-cleaning flexible materials with visible-light photocatalysis and antibacterial activities. ACS Appl Mater Interfaces 7:8076-8082. https://doi.org/10.1021/acsami.5b00633

Meulendijks N, Burghoorn M, van Ee R, Mourad M, Mann D, Keul H, Bex G, van Veldhoven E, Verheijen M, Buskens PBA (2017) Electrically conductive coatings consisting of Ag-decorated cellulose nanocrystals. Cellulose 24:2191-2204. https://doi.org/10.1007/s10570-017-1240$\mathrm{y}$

Miao YQ, Zheng CL (2010) Inhibiting effect of silver nanoparticles on influenza virus H1N1. Chin J New Drugs 19:605-611

Milosevic M, Radoicic M, Saponjic Z, Nunney T, Deeks C, Lazic V, Mitric M, Radetic T, Radetic M (2014) In situ photoreduction of $\mathrm{Ag}^{+}$-ions by $\mathrm{TiO}_{2}$ nanoparticles deposited on cotton and cotton/PET fabrics. Cellulose 21:3781-3795. https://doi.org/10.1007/s10570-014-03735

Mishra A, Butola BS (2017) Deposition of Ag doped $\mathrm{TiO}_{2}$ on cotton fabric for wash durable UV protective and antibacterial properties at very low silver concentration. Cellulose 24:3555-3571. https://doi.org/10.1007/s10570017-1352-4

Mohamed AL, El-Naggar ME, Shaheen TI, Hassabo AG (2017) Laminating of chemically modified silan based nanosols for advanced functionalization of cotton textiles. Int J Biol Macromol 95:429-437. https://doi.org/10.1016/j.ijbiomac. 2016.10.082

Montazer M, Alimohammadi F, Shamei A, Rahimi M (2012a) Durable antibacterial and cross-linking cotton with colloidal silver nanoparticles and butane tetra carboxylic acid 
without yellowing. Colloid Surface B 89:196-202. https:// doi.org/10.1016/j.colsurfb.2011.09.015

Montazer M, Alimohammadi F, Shamei A, Rahimi M (2012b) In situ synthesis of nano silver on cotton using Tollens' reagent. Carbohyd Polym 87:1706-1712. https://doi.org/ 10.1016/j.carbpol.2011.09.079

Montazer M, Dastjerdi M, Azdaloo M, Rad MM (2015) Simultaneous synthesis and fabrication of nano $\mathrm{Cu}_{2} \mathrm{O}$ on cellulosic fabric using copper sulfate and glucose in alkali media producing safe bio- and photoactive textiles without color change. Cellulose 22:4049-4064. https://doi.org/10. 1007/s10570-015-0764-2

Monteiro AS, Domeneguetti RR, Man MWC, Barud HS, Teixeira-Neto E, Ribeiro SJL (2019) Bacterial cellulose$\mathrm{SiO}_{2} @ \mathrm{TiO}_{2}$ organic-inorganic hybrid membranes with self-cleaning properties. J Sol-Gel Sci Techn 89:2-11. https://doi.org/10.1007/s10971-018-4744-5

Morais DS, Guedes RM, Lopes MA (2016) Antimicrobial approaches for textiles: from research to market. Materials 9:498. https://doi.org/10.3390/ma9060498

Mori Y, Ono T, Miyahira Y, Nguyen VQ, Matsui T, Ishihara M (2013) Antiviral activity of silver nanoparticle/chitosan composites against $\mathrm{H} 1 \mathrm{~N} 1$ influenza A virus. Nanoscale Res Lett 8:93. https://doi.org/10.1186/1556-276X-8-93

Nadi A, Boukhriss A, Bentis A, Jabrane E, Gmouh S (2018) Evolution in the surface modification of textile: a review. Text Prog 50:67-108. https://doi.org/10.1080/00405167. 2018.1533659

Nguyen VQ, Ishihara M, Kinoda J, Hattori H, Nakamura S, Ono T, Miyahira Y, Matsui T (2014) Development of antimicrobial biomaterials produced from chitin-nanofiber sheet/ silver nanoparticle composites. J Nanobiotechnol 12:49. https://doi.org/10.1186/s12951-014-0049-1

Nie XL, Wu SL, Mensah A, Wang QQ, Huang FL, Li DW, Wei QF (2020) Insight into light-driven antibacterial cotton fabrics decorated by in situ growth strategy. J Colloid Interf Sci 579:233-242. https://doi.org/10.1016/j.jcis.2020.06. 038

Oda AM, Khuder H, Hashim R, Rasheed A, Hasan AA, Hazim H, Raheem Z (2016) Photocatalytic degradation of safranin $\mathrm{O}$ by $\mathrm{ZnO}-\mathrm{Ag}$ loaded on cotton fabric. Res J Pharm biol Chem Sci 7:2915-2924

Onar N, Aksit AC, Sen Y, Mutlu M (2011) Antimicrobial, UV protective and self-cleaning properties of cotton fabrics coated by dip-coating and solvothermal coating methods. Fiber Polym 12:461-470. https://doi.org/10.1007/s12221011-0461-1

Parashar V, Parashar R, Sharma B, Pandey AC (2009) Parthenium leaf extract mediated synthesis of silver nanoparticles: a novel approach towards weed utilization. Dig J Nanomater Bios 4:45-50

Park SY, Chung JW, Priestley RD, Kwak SY (2012) Covalent assembly of metal nanoparticles on cellulose fabric and its antimicrobial activity. Cellulose 19:2141-2151. https:// doi.org/10.1007/s10570-012-9773-6

Paszkiewicz M, Golabiewska A, Rajski L, Kowal E, Sajdak A, Zaleska-Medynska A (2016) The antibacterial and antifungal textile properties functionalized by bimetallic nanoparticles of $\mathrm{Ag} / \mathrm{Cu}$ with different structures. J Nanomater 2016:6056980. https://doi.org/10.1155/2016/ 6056980
Perelshtein I, Applerot G, Perkas N, Guibert G, Mikhailov S, Gedanken A (2008) Sonochemical coating of silver nanoparticles on textile fabrics (nylon, polyester and cotton) and their antibacterial activity. Nanotechnology 19:245705. https://doi.org/10.1088/0957-4484/19/24/ 245705

Perelshtein I, Ruderman Y, Perkas N, Beddow J, Singh G, Vinatoru M, Joyce E, Mason TJ, Blanes M, Molla K, Gedanken A (2013) The sonochemical coating of cotton withstands 65 washing cycles athospital washing standards and retains its antibacterial properties. Cellulose 20:1215-1221. https://doi.org/10.1007/s10570-013-9929$\mathrm{Z}$

Perumalraj R, Anilkumar A, Devi ASN, Saranya B, Deepa P, Karthika R, Maheshwari N (2011) Silver-filled electrically conductive epoxy and silver nitrate-plated textile composite materials for EMC. J Reinf Plast Comp 30:203-215. https://doi.org/10.1177/0731684410391508

Perumalraj R, Narayanan KS (2014) Nano silver conductive composite material for electromagnetic compatibility. J Reinf Plast Comp 33:1000-1016. https://doi.org/10.1177/ 0731684414523059

Petrik IS, Eremenko AM, Naumenko AP, Rudenko AV (2020) Effect of silver and copper nanoparticles on adsorption and fluorescence of tryptophan on the surface of bactericidal textile. Appl Nanosci 10:2557-2562. https://doi.org/10. 1007/s13204-020-01315-Z

Potiyaraj P, Kumlangdudsana P, Dubas ST (2007) Synthesis of silver chloride nanocrystal on silk fibers. Mater Lett 61:2464-2466. https://doi.org/10.1016/j.matlet.2006.09. 039

Rahman KU, Ferreira-Neto EP, Rahman GU, Parveen R, Monteiro AS, Rahman G, Le QV, Domeneguetti RR, Ribeiro SJL, Ullah S (2021) Flexible bacterial cellulosebased $\mathrm{BC}-\mathrm{SiO}_{2}-\mathrm{TiO}_{2}-\mathrm{Ag}$ membranes with self-cleaning, photocatalytic, antibacterial and UV-shielding properties as a potential multifunctional material for combating infections and environmental applications. J Environ Chem Eng 9:104708. https://doi.org/10.1016/j.jece.2020.104708

Rana M, Hao B, Mu L, Chen L, Ma PC (2016) Development of multi-functional cotton fabrics with $\mathrm{Ag} / \mathrm{AgBr}-\mathrm{TiO}_{2}$ nanocomposite coating. Compos Sci Technol 122:104-112. https://doi.org/10.1016/j.compscitech.2015. 11.016

Ranjbar-Mohammadi M (2018) Production of cotton fabrics with durable antibacterial property by using gum tragacanth and silver. Int J Biol Macromol 109:476-482. https:// doi.org/10.1016/j.ijbiomac.2017.12.093

Rehan M, Khattab TA, Barohum A, Gatjen L, Wilken R (2018) Development of $\mathrm{Ag} / \mathrm{AgX}(\mathrm{X}=\mathrm{Cl}, \mathrm{I})$ nanoparticles toward antimicrobial, UV-protected and self-cleanable viscose fibers. Carbohyd Polym 197:227-236. https://doi.org/10. 1016/j.carbpol.2018.06.010

Rehan M, Mashaly HM, Mowafi S, El-Kheir AA, Emam HE (2015) Multi-functional textile design using in-situ Ag NPs incorporation into natural fabric matrix. Dyes Pigments 118:9-17. https://doi.org/10.1016/j.dyepig.2015.02.021

Rubin HN, Neufeld BH, Reynolds MM (2018) Surface-anchored metal-organic framework-cotton material for tunable antibacterial copper delivery. ACS Appl Mater 
Interfaces 10:15189-15199. https://doi.org/10.1021/ acsami.7b19455

Sedighi A, Montazer M, Hemmatinejad N (2014a) Copper nanoparticles on bleached cotton fabric: in situ synthesis and characterization. Cellulose 21:2119-2132. https://doi. org/10.1007/s10570-014-0215-5

Sedighi A, Montazer M, Samadi N (2014b) Synthesis of nano $\mathrm{Cu} 2 \mathrm{O}$ on cotton: Morphological, physical, biological and optical sensing characterizations. Carbohydr Polym 110:489-498. j.carbpol.2014b.04.030

Selvam S, Gandhi RR, Suresh J, Gowri S, Ravikumar S, Sundrarajan M (2012) Antibacterial effect of novel synthesized sulfated $\beta$-cyclodextrin crosslinked cotton fabric and its improved antibacterial activities with $\mathrm{ZnO}, \mathrm{TiO}_{2}$ and $\mathrm{Ag}$ nanoparticles coating. Int $\mathrm{J}$ Pharmaceut 434:366-374. https://doi.org/10.1016/j.ijpharm.2012.04.069

Shahidi S, Rashidi A, Ghoranneviss M, Anvari A, Rahimi MK, Moghaddam MB, Wiener J (2010) Investigation of metal absorption and antibacterial activity on cotton fabric modified by low temperature plasma. Cellulose 17:627-634. https://doi.org/10.1007/s10570-010-9400-3

Shahid-ul-Islam, Butola BS, Mohammad F (2016) Silver nanomaterials as future colorants and potential antimicrobial agents for natural and synthetic textile materials. RSC Adv 6:44232-44247. https://doi.org/10.1039/c6ra05799c

Shen ZM, Feng JC (2018) Highly thermally conductive composite films based on Nanofibrillated Cellulose in Situ Coated with a Small Amount of Silver Nanoparticles. ACS APPLIED MATERIALS INTERFACES 10:24193-24200. https://doi.org/10.1021/acsami.8b07249

Sing J, Srivastava M, Roychoudhury A, Lee DW, Lee SH, Malhotra BD (2013) Bienzyme-functionalized monodispersed biocompatible cuprous oxide/chitosan nanocomposite platform for biomedical application. J Phys Chem B 117:141-152. https://doi.org/10.1021/jp309639w

Slamborova I, Zajicova V, Karpiskova J, Exnar P, Stibor I (2013) New type of protective hybrid and nanocomposite hybrid coatings containing silver and copper with an excellent antibacterial effect especially against MRSA. Mater Sci Eng C 33:265-273. https://doi.org/10.1016/j. msec.2012.08.039

Suryaprabha T, Sethuraman MG (2017) Design of electrically conductive superhydrophobic antibacterial cotton fabric through hierarchical architecture using bimetallic deposition. J Alloy Compd 724:240-248. https://doi.org/10.1016/ j.jallcom.2017.07.009

Takeshima T, Tada Y, Sakaguchi N, Watari F, Fugetsu B (2015) DNA/Ag nanoparticles as antibacterial agents against gram-negative bacteria. Nanomaterials 5:284-297. https:// doi.org/10.3390/nano5010284

Tan YJ, Li J, Gao Y, Li J, Guo SY, Wang M (2018) A facile approach to fabricating silver-coated cotton fiber non-woven fabrics for ultrahigh electromagnetic interference shielding. Appl Surf Sci 458:236-244. https://doi.org/10. 1016/j.apsusc.2018.07.107

Tang B, Kaur J, Sun L, Wang X (2013) Multifunctionalization of cotton through in situ green synthesis of silver nanoparticles. Cellulose 20:3053-3065. https://doi.org/10. 1007/s10570-013-0027-z
Tang YJ, He ZB, Mosseler JA, Ni YH (2014) Production of highly electro-conductive cellulosic paper via surface coating of carbon nanotube/graphene oxide nanocomposites using nanocrystalline cellulose as a binder. Cellulose 21:4569-4581. https://doi.org/10.1007/s10570-014-04189

Tomsic B, Simoncic B, Orel B, Zerjav M, Schroers H, Simoncic A, Samardzija Z, Samardzija Z (2009) Antimicrobial activity of $\mathrm{AgCl}$ embedded in a silica matrix on cotton fabric. Carbohyd Polym 75:618-626. https://doi.org/10. 1016/j.carbpol.2008.09.013

Vankar PS, Shukla D (2012) Biosynthesis of silver nanoparticles using lemon leaves extract and its application for antimicrobial finish on fabric. Appl Nanosci 2:163-168. https://doi.org/10.1007/s13204-011-0051-y

Van Viet P, Phan BT, Mott D, Maenosono S, Sang TT, Thi CM, Van Hieu L (2018) Silver nanoparticle loaded $\mathrm{TiO}_{2}$ nanotubes with high photocatalytic and antibacterial activity synthesized by photoreduction method. J Photoch Photobio A 352:106-112. https://doi.org/10.1016/j.jphotochem. 2017.10.051

Varesano A, Aluigi A, Florio L, Fabris R (2009) Multifunctional cotton fabrics. Synthetic Met 159:1082-1089. https://doi. org/10.1016/j.synthmet.2009.01.036

Wang B, Li J, Wang GY, Liang WX, Zhang YB, Shi L, Guo ZG, Liu WM (2013) Methodology for robust superhydrophobic fabrics and sponges from in situ growth of transition metal/ metal oxide nanocrystals with thiol modification and their applications in oil/water separation. ACS Appl Mater Interfaces 5:1827-1839. https://doi.org/10.1021/ am303176a

Wang C, Guo RH, Lan JW, Jiang SX, Zhang ZY (2017a) Microwave-assisted synthesis of silver/reduced graphene oxide on cotton fabric. Cellulose 24:4045-4055. https://doi.org/10.1007/s10570-017-1392-9

Wang CX, Ren Y, Lv JC, Zhou QQ, Ma ZP, Qi ZM, Zhang W (2017b) In situ synthesis of silver nanoparticles on the cotton fabrics modified by plasma induced vapor phase graft polymerization of acrylic acid for durable multifunction. Appl Surf Sci 396:1840-1848. https://doi.org/ 10.1016/j.apsusc.2016.11.173

Wang ML, Zhang MJ, Zhang MX, Aizezi M, Zhang YM, Hu JT, Wu GZ (2019) In-situ mineralized robust polysiloxane$\mathrm{Ag} @ \mathrm{ZnO}$ on cotton for enhanced photocatalytic and antibacterial activities. Carbohyd Polym 217:15-25. https://doi.org/10.1016/j.carbpol.2019.04.042

Wasim M, Khan MR, Mushtaq M, Naeem A, Han MC, Wei QF (2020) Surface modification of bacterial cellulose by copper and zinc oxide sputter coating for UV-resistance/antistatic/antibacterial characteristics. Coatings 10:364. https://doi.org/10.3390/coatings 10040364

Wei DD, Dong CH, Liu J, Zhang Z, Lu Z (2019) A novel cyclic polysiloxane linked by guanidyl groups used as flame retardant and antimicrobial agent on cotton fabrics. Fiber Polym 20:1340-1346. https://doi.org/10.1007/s12221019-9008-7 ()

Wu D, Wang L, Song X, Tan Y (2013) Enhancing the visiblelight-induced photocatalytic activity of the self-cleaning $\mathrm{TiO}_{2}$-coated cotton by loading $\mathrm{Ag} / \mathrm{AgCl}$ nanoparticles. Thin Solid Films 540:36-40. https://doi.org/10.1016/j.tsf. 2013.05.113 
Wu M, Ma B, Pan T, Chen S, Sun J (2016) Silver-nanoparticlecolored cotton fabrics with tunable colors and durable antibacterial and self-healing superhydrophobic properties. Adv Funct Mater 26:569-576. https://doi.org/10.1002/ adfm.201504197

Xu H, Shi X, Ma H, Lv YH, Zhang LP, Mao ZP (2011) The preparation and antibacterial effects of dopa-cotton/ AgNPs. Appl Surf Sci 257:6799-6803. https://doi.org/10. 1016/j.apsusc.2011.02.129

Xu QB, Gu JY, Zhao Y, Ke XT, Liu XD (2017a) Antibacterial cotton fabric with enhanced durability prepared using $\mathrm{L}^{-}$ cysteine and silver nanoparticles. Fiber Polym 18:2204-2211. https://doi.org/10.1007/s12221-017-7567$\mathrm{Z}$

Xu QB, Xie LJ, Diao H, Li F, Zhang YY, Fu FY, Liu XD (2017b) Antibacterial cotton fabric with enhanced durability prepared using silver nanoparticles and carboxymethyl chitosan. Carbohyd Polym 177:187-193. https://doi.org/10.1016/j.carbpol.2017.08.129

Xu QB, Ke XT, Cai DR, Zhang YY, Fu FY, Endo T, Liu XD (2018a) Silver-based, single-sided antibacterial cotton fabrics with improved durability via an ${ }_{\mathrm{L}}$-cysteine binding effect. Cellulose 25:2129-2141. https://doi.org/10.1007/ s10570-018-1689-3

Xu QB, Ke XT, Shen LW, Ge NQ, Zhang YY, Fu FY, Liu XD (2018b) Surface modification by carboxymethy chitosan via pad-dry-cure method for binding Ag NPs onto cotton fabric. Int J Biol Macromol 111:796-803. https://doi.org/ 10.1016/j.ijbiomac.2018.01.091

Xu QB, Ke XT, Ge NQ, Shen LW, Zhang YY, Fu FY, Liu XD (2018c) Preparation of copper nanoparticles coated cotton fabrics with durable antibacterial properties. Fiber Polym 19:1004-1013. https://doi.org/10.1007/s12221-018-80675

Yue XX, Lin HT, Yan T, Zhang DS, Lin H, Chen YY (2014) Synthesis of silver nanoparticles with sericin and functional finishing to cotton fabrics. Fiber Polym 15:716-722. https://doi.org/10.1007/s12221-014-0716-8

Yuranova T, Rincon AG, Pulgarin C, Laub D, Xantopoulos N, Mathieu HJ, Kiwi J (2006) Performance and characterization of $\mathrm{Ag}$-cotton and $\mathrm{Ag} / \mathrm{TiO}_{2}$ loaded textiles during the abatement of E. coli. J Photoch Photobio A 181:363-369. https://doi.org/10.1016/j.jphotochem.2005. 12.020

Zahran MK, Ahmed HB, El-Rafie MH (2014) Surface modification of cotton fabrics for antibacterial application by coating with AgNPs-alginate composite. Carbohyd Polym 108:145-152. https://doi.org/10.1016/j.carbpol.2014.03. 005

Zhang C, Gu YN, Teng GX, Wang LP, Jin XD, Qiang ZW, Ma WG (2020) Fabrication of a double-shell $\mathrm{Ag} / \mathrm{AgCl} / \mathrm{G}$ $\mathrm{ZnFe}_{2} \mathrm{O}_{4}$ nanocube with enhanced light absorption and superior photocatalytic antibacterial activity. ACS Appl Mater Interfaces 12:29883-29898. https://doi.org/10.1021/ acsami.0c01476

Zhang CN, Uchikoshi T, Ichinose I, Liu LH (2019) Surface modification on cellulose nanofibers by $\mathrm{TiO}_{2}$ coating for achieving high capture efficiency of nanoparticles. Coatings 9:139. https://doi.org/10.3390/coatings9020139

Zhang D, Liao YF, Lin H, Chen YY (2014) One-step in situ preparation of nano $\mathrm{Ag}-\mathrm{ZnO}$ on cotton fabric for multifunctional finishing. J Text Res 35:92-97

Zhang DS, Chen L, Zang CF, Chen YY, Lin H (2013) Antibacterial cotton fabric grafted with silver nanoparticles and its excellent laundering durability. Carbohyd Polym 92:2088-2094. https://doi.org/10.1016/j.carbpol.2012.11. 100

Zhang F, Wu X, Chen Y, Lin H (2009) Application of silver nanoparticles to cotton fabric as an antibacterial textile finish. Fiber Polym 10:496-501. https://doi.org/10.1007/ s12221-009-0496-8

Zhang YY, Xu QB, Fu FY, Liu XD (2016) Durable antimicrobial cotton textiles modified with inorganic nanoparticles. Cellulose 23:2791-2808. https://doi.org/10.1007/s10570016-1012-0

Publisher's Note Springer Nature remains neutral with regard to jurisdictional claims in published maps and institutional affiliations. 